\title{
Atmospheric regional climate projections for the Baltic Sea region until 2100
}

\author{
Ole Bøssing Christensen ${ }^{1}$, Erik Kjellström ${ }^{2}$, Christian Dieterich ${ }^{2, \dagger}$, Matthias Gröger ${ }^{3}$, and \\ Hans Eberhard Markus Meier ${ }^{3,2}$ \\ ${ }^{1}$ National Centre for Climate Research (NCKF), Danish Meteorological Institute, Copenhagen, Denmark \\ ${ }^{2}$ Research and Development Department, Swedish Meteorological \\ and Hydrological Institute, Norrköping, Sweden \\ ${ }^{3}$ Department of Physical Oceanography and Instrumentation, Leibniz Institute for \\ Baltic Sea Research Warnemünde, Rostock, Germany \\ $\boldsymbol{t}_{\text {deceased }}$
}

Correspondence: Ole Bøssing Christensen (obc@dmi.dk)

Received: 29 June 2021 - Discussion started: 17 August 2021

Revised: 1 December 2021 - Accepted: 10 December 2021 - Published: 24 January 2022

\begin{abstract}
The Baltic Sea region is very sensitive to climate change; it is a region with spatially varying climate and diverse ecosystems, but it is also under pressure due to a high population in large parts of the area. Climate change impacts could easily exacerbate other anthropogenic stressors such as biodiversity stress from society and eutrophication of the Baltic Sea considerably. Therefore, there has been a focus on estimations of future climate change and its impacts in recent research. In this overview paper, we will concentrate on a presentation of recent climate projections from $12.5 \mathrm{~km}$ horizontal resolution atmosphere-only regional climate models from Coordinated Regional Climate Downscaling Experiment - European domain (EURO-CORDEX). Comparison will also be done with corresponding prior results as well as with coupled atmosphere-ocean regional climate models. The recent regional climate model projections strengthen the conclusions from previous assessments. This includes a strong warming, in particular in the north in winter. Precipitation is projected to increase in the whole region apart from the southern half during summer. Consequently, the new results lend more credibility to estimates of uncertainties and robust features of future climate change. Furthermore, the larger number of scenarios gives opportunities to better address impacts of mitigation measures. In simulations with a coupled atmosphere-ocean model, the climate change signal is locally modified relative to the corresponding standalone atmosphere regional climate model. Differences are largest in areas where the coupled system arrives at different sea-surface temperatures and sea-ice conditions.
\end{abstract}

1

For many years, hundreds of global climate projections have been produced according to various scenarios of future greenhouse gas emissions and other forcing factors including changes in aerosols and land use. This has been coordinated in model intercomparison projects (MIPs) that have provided fundamental input to the Working Group I assessment reports of the Intergovernmental Panel on Climate Change (IPCC; IPCC, 2001, 2007, 2013, 2021). The fifth IPCC Assessment
Report (AR5; IPCC, 2013) was built on the World Climate Research Programme's (WCRP) Coupled Model Intercomparison Project phase 5 (CMIP5) multi-model data (Taylor et al., 2012). Many general circulation models (GCMs) participated in simulations according to several Representative Concentration Pathway (RCP) scenarios (van Vuuren et al., 2011). The most recent, sixth, Assessment Report (IPCC, 2021; AR6) builds on the successor, CMIP6 (Eyring et al., 2016), that involves a new set of Shared Socioeconomic Pathway (SSP) scenarios (O'Neill et al., 2017). This has, how- 
ever, not been addressed here as, at this point, downscaling activities based on CMIP6 projections are still lacking.

The Baltic Sea region is highly diverse with considerable spatial variability over small distances compared to typical GCM resolutions. Consequently, GCMs do not represent all relevant processes at adequate scales and results are often biased (e.g. Graham et al., 2008). High-resolution regional climate models, nested in the GCMs, have been shown to add value to the GCM results and to promote detailed analysis on regional to local scales (e.g. Giorgi and Gao, 2018). At the European level, considerable efforts have therefore been undertaken to downscale GCM simulations to a higher horizontal resolution with RCMs. The history of coordinated RCM simulations started in the Prediction of Regional Scenarios and Uncertainties for Defining European Climate Change Risks and Effects (PRUDENCE) project with RCMs mostly operated at $50 \mathrm{~km}$ spatial resolution (Christensen and Christensen, 2007), continued with the Ensemble-based Predictions of Climate Changes and their Impacts (ENSEMBLES) project (van der Linden and Mitchell, 2009; Hanel and Buishand, 2011; Kyselý et al., 2011; Räisänen and Eklund, 2011; Déqué et al., 2012; Kjellström et al., 2013) and more recently in the EURO-CORDEX initiative, which forms part of the Coordinated Regional climate Downscaling EXperiment (CORDEX, https://cordex.org/, last access: 14 January 2022; e.g. Giorgi et al., 2006; Jacob et al., 2014; Kotlarski et al., 2014; Keuler et al., 2016; Kjellström et al., 2018). Most recently, the European Copernicus Climate Change Services has supported an extension of the available CMIP5-driven RCM downscaling simulations in the EURO-CORDEX setup with around $12 \mathrm{~km}$ spatial resolution (Vautard et al., 2021; Coppola et al., 2021). This has led to the public availability of a large amount, currently 127 , of different simulations following the RCP2.6, RCP4.5, and RCP8.5 scenarios (some simulations with known errors are not counted).

Regional climate models have been used not only for downscaling of climate change scenarios. Also, observationbased reanalysis datasets have been extensively downscaled with RCMs in recent years (e.g. Feser et al., 2001; Hagemann et al., 2004; Christensen et al., 2010; Samuelsson et al., 2011; Kotlarski et al., 2014; Prein et al., 2015). These experiments are useful for comparing RCM results and observational data for recent decades, and thereby for evaluation of RCM models. The RCMs are found to capture many features of the climate in a realistic way, albeit with some systematic errors and biases (Wibig et al., 2015; Kjellström and Christensen, 2020). As a remedy, bias correction is sometimes applied to the results (e.g. Dosio et al., 2016). Biases are generally larger when GCMs are downscaled instead of reanalysis data, as these show systematic biases in their representation of the atmospheric circulation at large scales, of temperature, humidity, and sea-surface conditions. For an area like the Baltic Sea region, this implies that sea-surface temperatures (SSTs) and sea ice from the coarse-scale driving GCM may not be completely adequate as input to an RCM; this constitutes an additional source of potential uncertainty of the downscaled regional scenarios (Kjellström and Ruosteenoja, 2007).

During the past decades, a number of regional coupled atmosphere-ocean-sea-ice models with focus on the Baltic Sea and adjacent marginal seas have therefore been developed for climate studies (e.g. Gustafsson et al., 1998; Döscher et al., 2002; Wang et al., 2015; Dieterich et al., 2019; Primo et al., 2019; Kelemen et al., 2019; Akhtar et al., 2019; Sein et al., 2020). In these models, prescribed boundary conditions at the sea surface (i.e. sea ice and SST) were replaced by online coupled ocean models allowing for a direct and more realistic representation of air-sea thermal feedback mechanisms (see review by Gröger et al., 2021b). These coupled models exhibit a different model solution for many climate variables compared to their atmosphere stand-alone counterparts, especially over the coupled region (Gröger et al., 2015; Ho-Hagemann et al., 2017; Primo et al., 2019; Gröger et al., 2019, 2021a). The most recent and largest ensemble of regional coupled climate change simulations was provided by Dieterich et al. (2019) and Gröger et al. (2019, 2021a), and is based on the Rossby Centre Regional Climate Model (RCA4) coupled interactively to the Nucleus for $\mathrm{Eu}-$ ropean Modelling of the Ocean (NEMO).

Available RCM literature describes extensive studies of possible future climate conditions for many areas, including the Baltic Sea basin (see, e.g. Lind and Kjellström, 2008; Kjellström and Lind, 2009; Benestad, 2011; Kjellström et al., 2011; Nikulin et al., 2011; Christensen et al., 2015a; Christensen and Kjellström, 2018; Coppola et al., 2021). Ensembles of climate projection simulations have been used to obtain probabilistic climate change information, both GCM (Lind and Kjellström, 2008; Räisänen, 2010) and RCM ensembles (Buser et al., 2010; Donat et al., 2011). In addition, the wider range of GCM scenarios has been used to set regional scenarios in a broader context (Lind and Kjellström, 2008; Kjellström et al., 2016, 2018).

This work aims at presenting climate change in the area around the Baltic Sea, as it is projected by the very large ensemble of EURO-CORDEX RCMs at $12 \mathrm{~km}$ resolution. The spread in results between the projections is used to discuss uncertainties in future climate change. In addition to the uncoupled atmosphere-only EURO-CORDEX RCM ensemble, we will also assess changes in an ensemble with the atmospheric regional model RCA4 coupled to the NEMO ocean model. A comparison between results from the stand-alone atmospheric model and the coupled model provides input to the assessment of uncertainties in future climate change projections for the area.

\section{Data and methods}

We will focus on data of the most commonly studied fields: surface air temperature, average total precipitation, mean 
wind speed at $10 \mathrm{~m}$ height, incoming short-wave radiation, and average winter snow and sea-ice cover. The consequences of extreme weather events impact many aspects of society. Extreme precipitation often results in flooding, which often causes extensive damage as do extreme winds in connection with low-pressure systems. Changes in these extremes as a result of anthropogenic climate change have received considerable attention. We will therefore also report on extremes of daily precipitation and $10 \mathrm{~m}$ wind speed.

The main results of this study build on seasonal means from the publicly available and accessible EURO-CORDEX data, which at the time of writing consisted of the 124 simulations indicated in Table 1 out of a current total of 127 . Three different emission scenarios have been widely used for downscaling within CORDEX. The RCP2.6 scenario is the most moderate and will require a targeted emission reduction worldwide. The RCP8.5 scenario, in contrast, is consistent with large future increases in emissions, little emission mitigation, and a continued reliance on fossil fuels for many decades. In the middle, the RCP4.5 scenario requires a considerable amount of mitigation but is very unlikely to achieve the $2 \%$ warming limit relative to pre-industrial conditions, which the Paris Agreement targets.

In this study, we will concentrate on the warmer RCP8.5 scenario. In the analysis, we will analyse three periods: 1981-2010, 2041-2070, and 2071-2100. Plots corresponding to the other scenarios can be found in the Supplement. In general, the amplitude of regional climate change for varying scenarios scales with temperature change, while the spatial pattern is similar (see, e.g. Christensen et al., 2015b). This means that the RCP8.5 scenario will show expected patterns of climate change with a relative minimum of noise from interannual variability of the simulations. Furthermore, the largest of all three RCP ensembles is the RCP8.5 one (Table 1); hence, the analysis of these scenario simulations allows the best estimate of model uncertainties and internal variability.

Not all EURO-CORDEX simulations have been analysed for every variable considered here; two WRF361H simulations do not contain solar radiation, and snow and sea ice from several simulations either do not exist in the archive or have not been downloaded. Some simulations with the Convection-Resolving Climate Model (crCLIM) are missing winter (DJF) 2005-2006 due to a problem when handling the transition between historical and scenario simulations; we have repeated DJF 2004-2005 in its place. All simulations driven by Hadley Centre Global Environment Model version 2 Earth system configuration (HadGEM2-ES) are missing the year 2100; for these simulations, we have used 20702099 as the end-of-century period.

The second Baltic Sea Experiment (BALTEX) Assessment of Climate Change for the Baltic Sea basin (BACC) report from 2015 (BACC II Author Team, 2015) showed similar maps to those presented here. These results were based on the ENSEMBLES database (van der Linden and Mitchell,
2009), consisting of simulations following the Special Report on Emissions Scenarios (SRES) (Nakićenović et al., 2000) A1B scenario performed in $25 \mathrm{~km}$ grid resolution. The periods compared were 1961-1990 and 2071-2100. The mean GCM global temperature change weighted with the number of RCM simulations in the ensemble, for the EUROCORDEX and ENSEMBLES simulations, can be seen in Table 2. Note that the first reference period differs between ENSEMBLES (1961-1990) and EURO-CORDEX (19812010).

To a high extent, maps over the Baltic Sea catchment of climate change for the weaker emission scenarios exhibit the same patterns as the RCP8.5 climate change normalized by global temperature change; maps are available in the Supplement.

The maps below show results based on 72 regional climate change simulations from the RCP8.5 EURO-CORDEX simulations listed in Table 1. Corresponding plots for other scenarios and periods can be found in the Supplement. For each location, the median among ensemble members of the change is shown together with the first and third quartiles. In the maps showing the median, we only display grid points where $75 \%$ of models agree on the sign, i.e. where both quartile plots show the same sign; elsewhere, we indicate in a white colour that the changes are not robust. We will discuss only DJF and summer (JJA) in this study. The scatter plots below show results for all simulations following the three commonly used scenarios (Table 1). Where possible, we also include results from the ENSEMBLES project, which were the basis of BACC II (Christensen et al., 2015a). In addition to the average over the entire Baltic Sea catchment region including the Baltic Sea, we divide the region into sea points and land points north and south of $60^{\circ} \mathrm{N}$. In the Supplement (Tables S1-S20), tables of ensemble means and ensemble standard deviations can be found for temperature and precipitation, for both periods, all scenarios (including the BACC II/ENSEMBLES SRES A1B scenario), and all five areas.

We will also investigate the coupled-model ensemble with RCA4-NEMO. RCA4 is set up for the EURO-CORDEX domain with a horizontal resolution of $\sim 25 \mathrm{~km}$ and 40 vertical levels. NEMO simulates the hydrodynamics of the Baltic Sea as well as the North Sea at $\sim 3.7 \mathrm{~km}$ resolution and 56 vertical levels (Gröger et al., 2015; Dieterich et al., 2019). Airsea fluxes are exchanged every $3 \mathrm{~h}$ between the ocean and the atmosphere. The RCA4-NEMO ensemble consists of 22 downscaled GCM simulations based on eight different global models for the historical period and the RCP2.6, RCP4.5, and RCP8.5 scenarios. In addition, there is also a reanalysisdriven simulation for the historical period.

These results will be compared to the corresponding RCA4 atmosphere-only simulations at $12.5 \mathrm{~km}$ resolution, which can be found in the EURO-CORDEX archive. When possible, these simulations are included in the scatter plots below. 
Table 1. Model simulations of the study. These constitute the entire set of seasonal average fields available from the Earth System Grid Federation (ESGF; http://esgf-data.dkrz.de, last access: 31 May 2021) archive in May 2021. There are 72 ensemble members following RCP8.5, 22 following RCP4.5, and 30 following RCP2.6.

\begin{tabular}{|c|c|c|c|c|c|c|c|c|c|c|c|c|}
\hline RCP8.5 & RCA4 & $\begin{array}{l}\text { CCLM4-8- } \\
17\end{array}$ & crCLIM & $\begin{array}{l}\text { REMO } \\
09,15\end{array}$ & \begin{tabular}{|l} 
RAC- \\
MO22E
\end{tabular} & $\begin{array}{l}\text { HIR- } \\
\text { HAM5 }\end{array}$ & $\begin{array}{l}\text { WRF361 } \\
\text { H }\end{array}$ & WRF381P & $\begin{array}{l}\text { ALADIN6 } \\
3\end{array}$ & \begin{tabular}{|l} 
RegCM4. \\
6.1
\end{tabular} & $\begin{array}{l}\text { HadREM } \\
\text { 3-GA7.05 }\end{array}$ & $\begin{array}{l}\text { Total } \\
\text { by } \\
\text { GCM }\end{array}$ \\
\hline MOHC-HadGEM2-ES & 1 & 1 & 1 & 1 & 1 & 1 & 1 & 1 & 1 & 1 & 1 & 11 \\
\hline ICHEC-EC-EARTH & 3 & 1 & 3 & 1 & 3 & 3 & 1 & 1 & & 1 & 1 & 18 \\
\hline $\begin{array}{l}\text { CNRM-CERFACS- } \\
\text { CNRM-CM5 } \\
\end{array}$ & & & 1 & 1 & 1 & 1 & & 1 & 1 & & 1 & 7 \\
\hline NCC-NorESM1-M & 1 & & 1 & 1 & 1 & 1 & & 1 & 1 & 1 & 1 & 9 \\
\hline MPI-M-MPI-ESM-LR & 3 & 1 & 3 & 3 & 1 & 1 & 1 & 1 & 1 & 1 & 1 & 17 \\
\hline IPSL-IPSL-CM5A-MR & 1 & & & 1 & 1 & 1 & & 1 & & & & 5 \\
\hline CCCma-CanESM2 & & 1 & & 1 & & & & & & & & 2 \\
\hline MIROC-MIROC5 & & 1 & & 1 & & & 1 & & & & & 3 \\
\hline Total by RCM & 9 & 5 & 9 & 10 & 8 & 8 & 4 & 6 & 4 & 4 & 5 & 72 \\
\hline RCP4.5 & RCA4 & \begin{tabular}{|l} 
CCLM4-8- \\
17 \\
\end{tabular} & crCLIM & $\begin{array}{l}\text { REMO } \\
09,15 \\
\end{array}$ & \begin{tabular}{|l} 
RAC- \\
MO22E \\
\end{tabular} & $\begin{array}{l}\text { HIR- } \\
\text { HAM5 } \\
\end{array}$ & $\begin{array}{l}\text { WRF361 } \\
\text { H }\end{array}$ & WRF381P & \begin{tabular}{|l} 
ALADIN6 \\
3
\end{tabular} & \begin{tabular}{|l} 
RegCM4. \\
6.1
\end{tabular} & \begin{tabular}{|l} 
HadREM \\
3-GA7.05
\end{tabular} & $\begin{array}{l}\text { Total } \\
\text { now }\end{array}$ \\
\hline MOHC-HadGEM2-ES & 1 & 1 & & 1 & 1 & 1 & & & & & & 5 \\
\hline ICHEC-EC-EARTH & 1 & 1 & & 1 & 2 & 1 & & & & & & 6 \\
\hline $\begin{array}{l}\text { CNRM-CERFACS- } \\
\text { CNRM-CM5 } \\
\end{array}$ & & & & & 1 & & & & 1 & & & 2 \\
\hline NCC-NorESM1-M & 1 & & & 1 & & 1 & & & & & & 3 \\
\hline MPI-M-MPI-ESM-LR & 1 & 1 & & 2 & & & & & & & & 4 \\
\hline IPSL-IPSL-CM5A-MR & 1 & & & & & & & 1 & & & & 2 \\
\hline Total by RCM & 5 & 3 & & 5 & 4 & 3 & & 1 & 1 & & & 22 \\
\hline RCP2.6 & RCA4 & $\begin{array}{l}\text { CCLM4-8- } \\
17\end{array}$ & crCLIM & $\begin{array}{l}\text { REMO } \\
09,15 \\
\end{array}$ & \begin{tabular}{|l} 
RAC- \\
MO22E \\
\end{tabular} & \begin{tabular}{|l|} 
HIR- \\
HAM5 \\
\end{tabular} & $\begin{array}{l}\text { WRF361 } \\
\text { H }\end{array}$ & WRF381P & $\begin{array}{l}\text { ALADIN6 } \\
3\end{array}$ & \begin{tabular}{|l} 
RegCM4. \\
6.1 \\
\end{tabular} & \begin{tabular}{|l|} 
HadREM \\
3-GA7.05 \\
\end{tabular} & $\begin{array}{l}\text { Total } \\
\text { now }\end{array}$ \\
\hline MOHC-HadGEM2-ES & 1 & & & 1 & 1 & 1 & & & & 1 & 1 & 6 \\
\hline ICHEC-EC-EARTH & 1 & 1 & & 1 & 1 & 1 & & & & & 1 & 6 \\
\hline $\begin{array}{l}\text { CNRM-CERFACS- } \\
\text { CNRM-CM5 } \\
\end{array}$ & & & & 1 & 1 & & & & 1 & & & 3 \\
\hline NCC-NorESM1-M & 1 & & & 1 & 1 & & & & & 1 & & 4 \\
\hline MPI-M-MPI-ESM-LR & 1 & 1 & & 2 & 1 & & 1 & & & 1 & & 7 \\
\hline IPSL-IPSL-CM5A-MR & & & & 1 & & & & & & & & 1 \\
\hline NOAA-GFDL-ESM2G & & & & 1 & & & & & & & & 1 \\
\hline MIROC-MIROC5 & & 1 & & 1 & & & & & & & & 2 \\
\hline Total by RCM & 4 & 3 & & 9 & 5 & 2 & 1 & & 1 & 3 & 2 & 30 \\
\hline Grand total by GCM & 18 & 11 & 9 & 24 & 17 & 13 & 5 & 7 & 6 & 7 & 7 & 124 \\
\hline
\end{tabular}

Table 2. Average global warming from driving GCMs in each scenario, weighted by the number of downscaling simulations of each. The warming is presented relative to the reference period 1981-2010 for mid-century (2041-2070) and end-of-century (2071-2100) conditions.

\begin{tabular}{llrrr}
\hline Project & Scenario & Ensemble size & Mid-century warming & End-of-century warming \\
\hline ENSEMBLES & SRES A1B & 13 & - & 3.00 \\
EURO-CORDEX & RCP8.5 & 72 & 2.21 & 3.71 \\
EURO-CORDEX & RCP4.5 & 22 & 1.67 & 2.13 \\
EURO-CORDEX & RCP2.6 & 30 & 1.22 & 1.19 \\
\hline
\end{tabular}




\section{Results and discussion}

\subsection{Temperature}

According to the analysed EURO-CORDEX ensemble, we will see increasing air temperature in the Baltic Sea area during the present century. According to this ensemble, it is a robust result for all seasons, locations, simulations, and scenarios.

For both seasons analysed (winter and summer), the temperature change shows spatial gradients with the strongest warming in the northeast (Fig. 1). Winter warming is larger than summer warming and larger than the global average warming of about $3.7 \%$ (Table 2); in the northeast, it approaches twice the global average warming. Larger warming than the global average is generally expected for land areas, since land heats more quickly than sea areas where also enhanced evaporation tends to reduce warming (e.g. Sutton et al., 2007); it is most clearly seen in winter in the eastern part of the area. The strong winter increase is also influenced by the feedback mechanisms involving retreating snow and sea ice. There is a general pattern of higher warming in the north than in the south, but there is a spread in the magnitude of the change. This is illustrated in the columns of the figures below. As only eight GCMs have been used for these RCP8.5 RCM experiments, the spread between quartiles could be lower than what would have come from an exhaustive downscaling of all CMIP5 global simulations; Kjellström et al. (2016) compared nine GCMs, including the eight GCMs analysed here, to 25 other CMIP5 GCMs and found the nine-member-ensemble spread over Sweden to be comparable in summer but smaller than that in the larger GCM ensemble in winter.

Earlier studies have shown that the increase in winter temperatures is strongest for the coldest episodes (Kjellström, 2004) as well as for extreme daily maximum and minimum temperatures (Kjellström et al., 2007; Nikulin et al., 2011). There is a significant decrease in the probability of cold temperatures (Benestad, 2011). Warm summer extremes are projected to become more pronounced; for example, Nikulin et al. (2011) used an ensemble of six RCM simulations, all downscaling GCMs under the SRES A1B scenario; the data indicate that warm extremes with a present-day (1961-1990) return period of 20 years will be reached 4 times as often in Scandinavia by 2071-2100, with a frequency around once every 5 years in Scandinavia by 2071-2100.

Summer warming in the Baltic Sea basin is smaller than winter warming, and it is relatively homogeneous across the area. A tendency is seen for larger warming over land areas in the northernmost parts of the Baltic Sea basin. These areas are closest to the northern rim of Scandinavia and the Kola Peninsula where warming in summer is as high as that projected for parts of southernmost Europe (Kjellström et al., 2018). In the northeastern part of the region, a large warming may be related to the larger temperature increases further to the north in the Arctic, potentially connected with the ice-albedo and other feedback mechanisms (IPCC, 2021). The strong warming in the southeastern part of the Baltic Sea basin is related to the large-scale pattern of warming in Europe, where the strongest summer warming is seen in southern Europe. Similar results for other GCMRCM combinations have been reached in, e.g. Christensen and Christensen (2007), Kjellström et al. (2011), and Vautard et al. (2014). A potential source of difference between GCMs and RCMs is the different treatment of aerosols in these models. Many of the RCMs do not include time-varying anthropogenic aerosols leading to weaker future warming compared to GCMs (Boé et al., 2020). The EURO-CORDEXbased results are consistent with the RCM results for 20212050 in Déqué et al. (2012). This study found that there is a significant temperature response, even for the relatively short-term 2021-2050 time frame, even though the total uncertainty related to the choice of model combination (GCM$\mathrm{RCM}$ ) and sampling (natural variability) is large. Similarly, Kjellström et al. (2013) showed early emergence already in the first few decades of the 21 st century of trends in both winter and summer temperature despite large natural variability as represented in the ENSEMBLES RCM projections used in BACC II.

Corresponding changes in the daily minimum temperature and daily maximum temperature (not shown) have the same patterns as the average temperature change, with the expected larger magnitude of warming for minimum temperature. A range of factors may be responsible for this decrease in difference between minimum and maximum temperatures. This could involve changes in the diurnal temperature range (e.g. Lindvall and Svensson, 2015) or changes in the synoptic weather variability in combination with reduced large-scale temperature gradients between the Atlantic Ocean and the Eurasian continent (IPCC, 2021).

\subsection{Precipitation}

The multi-model EURO-CORDEX ensemble relative precipitation change for winter and summer is shown in Fig. 2. The ensemble is the same as that in Fig. 1.

During winter, the relative increases are quite homogeneous, although there are large differences between the lower and upper quartiles. These differences are largest west of the Baltic Sea catchment (Norway) where the amount of precipitation is particularly sensitive to different changes in the large-scale circulation. For summer, there is a clear pattern of more positive change in the north versus less positive change in the south. As expected, winter increases are projected to be larger than those in summer. Roughly, the winter increase is $25 \%-35 \%$ over most of the area in the median, and the summer increase is $15 \%-25 \%$ for the northern part of the area. This is consistent with the AR5 Climate Atlas, where median increases of precipitation in the area are 10\%-20\% for the winter half year and $5 \%-10 \%$ for summer, as these 
25th percentile
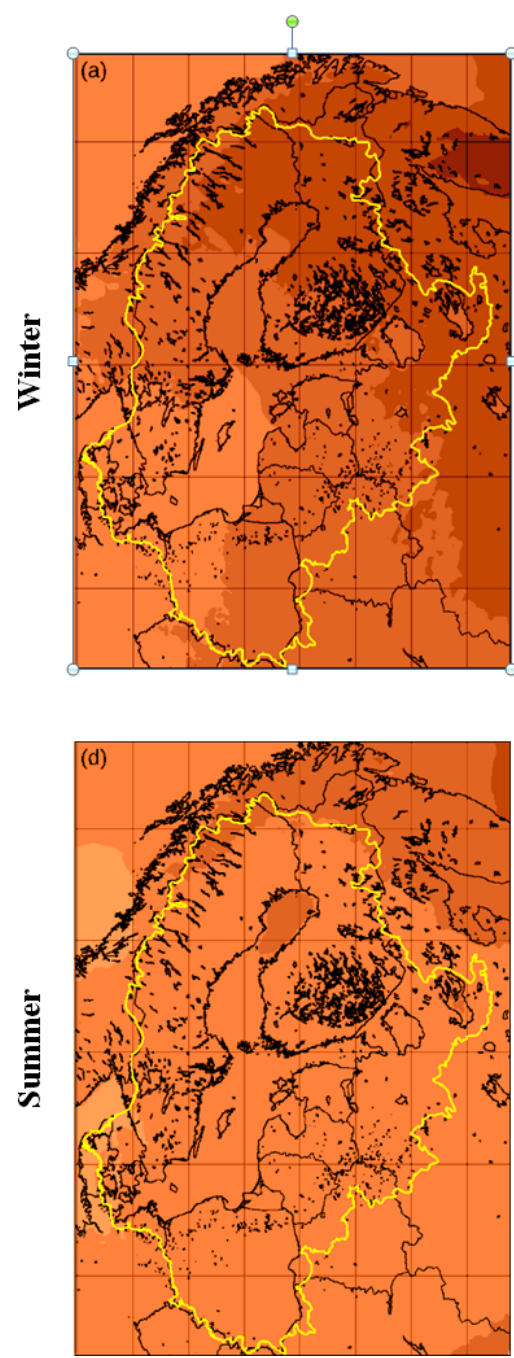

Median
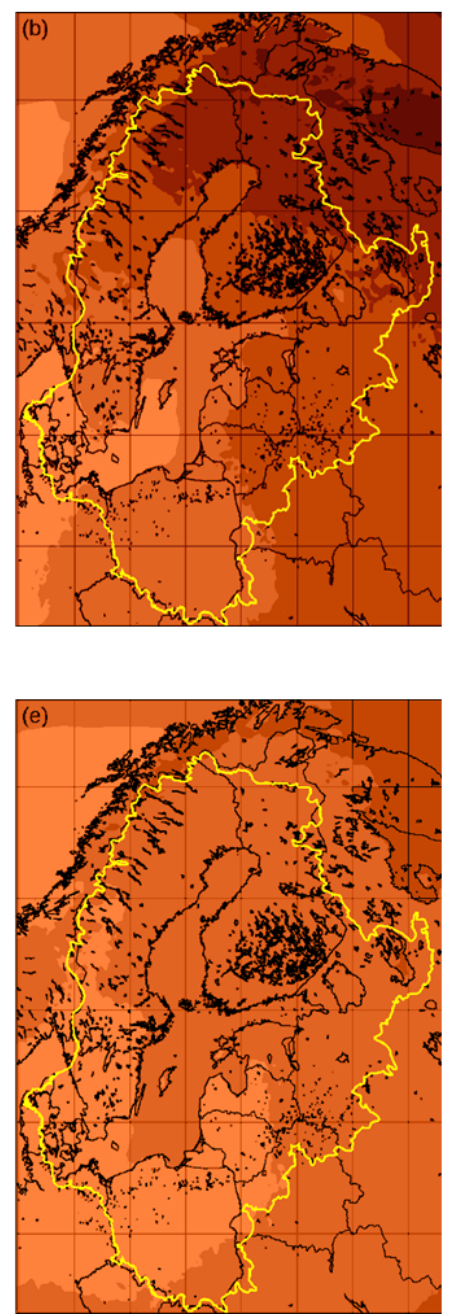

75th percentile
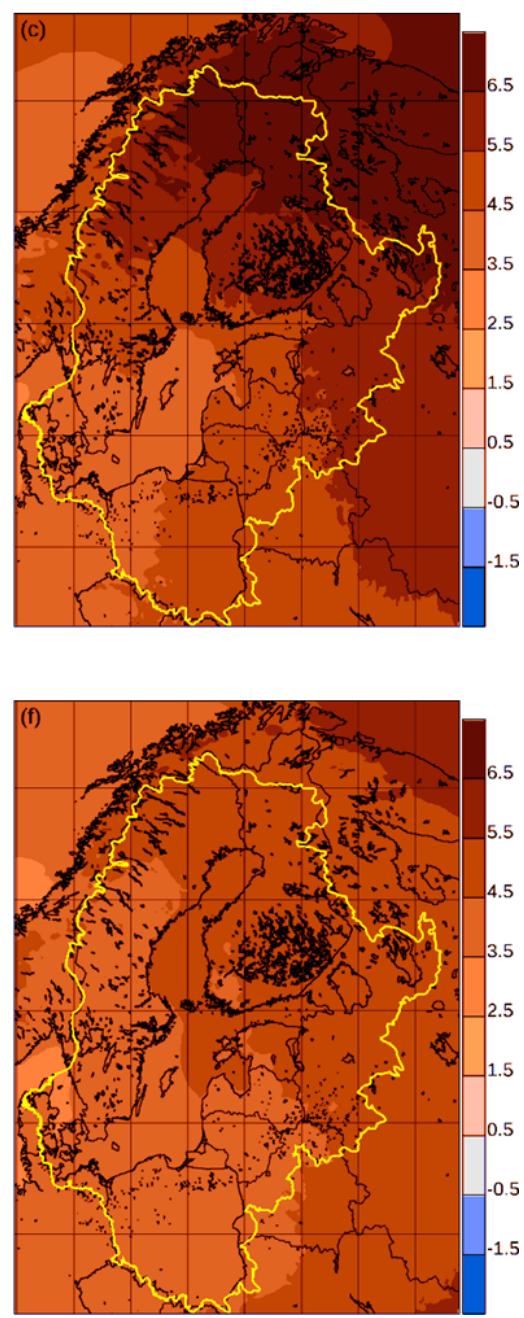

Figure 1. Temperature change between 1981-2010 and 2071-2100 for 72 simulations from EURO-CORDEX according to the RCP8.5 scenario. (a-c) Winter. (d-f) Summer. (a, d) Lowest quartile; (b, e) median value; (c, f) higher quartile. In all the following figures, panels (b, e) depicting pointwise median values are only coloured when $75 \%$ of the simulations agree on the sign of the change. The Baltic Sea catchment is indicated in yellow.

results correspond to the RCP4.5 scenario with around $2.5 \%$ of warming for the periods mapped, whereas the EUROCORDEX results correspond to a global warming of $3.8^{\circ} \mathrm{C}$.

For summer, there is disagreement on the sign of climate change for most of the southern half of the area, indicated by the masked-out area defined as regions where at least $25 \%$ of the models disagree on the sign with the majority. Since the period mapped here consists of the three summer months of June-August, whereas the AR5 Climate Atlas maps AprilSeptember, a comparison of the position of the no-change area is difficult. In an analysis of the older ENSEMBLES simulations (Déqué et al., 2012), almost all land points in the Baltic Sea region showed significantly positive summer precipitation signals.
This general picture of change is not surprising. Climate models generally project the global hydrological cycle to become more intense (e.g. Held and Soden, 2006). For Europe, this corresponds to increasing precipitation in northern Europe and decreasing precipitation in southern Europe, both in winter and summer (Christensen et al., 2007). Between these areas of projected increase and projected decrease, only small changes or changes in different directions are projected (see, e.g. Kjellström et al., 2011). The location of the transition zone depends on the season and is located farther to the south in winter than in summer. In summer, this zone shifts into the Baltic Basin: winter precipitation is projected to increase over the entire Baltic Sea catchment, while summer precipitation is mostly projected to only increase in the 
northern half of the basin. In the south, precipitation change is small for the ensemble mean, and there is a large spread between different models with both increases and decreases. Basically, both increases and decreases are possible in the future.

In Fig. 3, we show scatter plots where the relative change between 1981-2010 and 2071-2100 of precipitation is plotted against the corresponding change of temperature for each model and each scenario. Ensemble means for the three scenarios are indicated by the three larger symbols. This calculation has been performed for various subsets of the Baltic Sea catchment (see Fig. 1): the entire region; only land points; only sea points; only land points north and south of $60^{\circ} \mathrm{N}$, respectively.

There is a strong correlation between temperature and precipitation in winter with significant regression slopes of around five percentage points per degree and squared correlation coefficients of 0.5 to 0.6 depending on the sub-area. This is an indication of an approximate common sensitivity of precipitation change to local temperature change. This correspondence breaks down for summer, where the plots contain much more noise, indicating large model-dependent influences on the precipitation signal. The north-south gradient in summer precipitation change is apparent in the model averages (compare the northern and southern land point plots), but the inter-model spread is large.

Due to the roughly $20 \%$ higher average global warming in the current RCP8.5 ensemble than in the GCMs underlying BACC II (see Table 2), we would have expected general climate change to be around $20 \%$ larger for EURO-CORDEX RCP8.5 than those presented in BACC II. It is noteworthy that this difference is not generally seen in Fig. 3, where we have plotted temperature and precipitation change for the BACC II simulations (BACC II Author Team, 2015) along with the three scenarios of the present analysis. The BACC II results correspond to the RCP8.5 results both with respect to temperature and precipitation change apart from land areas in summer where the BACC II change is only about $80 \%$ of the RCP8.5 result ( $+6.5 \%$ vs. $+8.2 \%$ ).

In Christensen et al. (2019), a thorough comparison of change patterns of mean temperature and precipitation has been performed for the PRUDENCE simulations behind the first BACC report (BACC Author Team, 2008), the ENSEMBLES simulations behind the second report (BACC II Author Team, 2015), and the EURO-CORDEX data behind the present report. This analysis used patterns of change scaled with global temperature change and is therefore useful for pinpointing differences between the BACC reports extraneous to the variations of general scenario strength, i.e. differences in local sensitivity and/or change patterns apart from those due to differences in emission scenarios. The most important differences between BACC II and the current simulations are a slightly reduced winter warming per unit of global warming in EURO-CORDEX compared to BACC II; a smaller wintertime precipitation increase but a slightly larger increase of summer precipitation over the Baltic Sea. These conclusions do not contradict the results from Fig. 3, since a scaling with global warming would increase both local precipitation and local temperature changes for the BACC II ENSEMBLES results relative to RCP8.5.

\subsection{Extreme precipitation}

The water-holding capacity of the atmosphere increases with increasing temperature. Therefore, precipitation extremes are projected to increase with climate warming (e.g. Lenderink and van Meijgaard, 2010). Several studies, some of which are described in the following, indicate that extreme precipitation is likely to increase in the future, even in areas and seasons, where the average precipitation does not increase. One example is the IPCC Special Report on extreme events (Seneviratne et al., 2012), where it was shown that higher extremes of precipitation consistently show larger increases than lower extremes, and higher increases than averages.

Already simulations from the PRUDENCE project (Christensen and Christensen, 2003) showing a considerable decrease in average summer precipitation in large parts of southern Europe at the same time showed an increased probability of very extreme precipitation in that area as well as in the north, where average precipitation was not projected to decrease. Quite generally, more intense precipitation can be expected on all timescales, from single rain showers to synoptic-scale precipitation.

Nikulin et al. (2011) investigated an ensemble of RCM simulations following the SRES A1B scenario with the RCA model; they showed that the 20-year return value of precipitation extremes in Scandinavia in the period 1961-1990 was projected to decrease to 6-10 years in 2071-2100 for summer over northern Europe and to 2-4 years in winter. Similarly, Larsen et al. (2009) analysed a high-resolution RCM integration and reported that the return period for 20 -year rainfall events at hourly duration decreased to about 4 years for Sweden.

Collected results from 90 of the models from the EUROCORDEX project are illustrated in Fig. 4, along with results from the coupled models discussed below. For data availability reasons at the time of writing, not all simulations have been analysed for extreme precipitation. We will here use the 10 -year return value as representative of extreme precipitation. This is defined as the daily precipitation amount, which is only exceeded once every 10 years on average. The modelmedian signal has a consistently positive sign across the domain for the areas where more than $75 \%$ of the model results have the same sign. The temperature dependence of the increases in the Baltic Sea basin (slopes in Fig. 4) are generally larger in summer than in winter with the southern land points as an exception, the same area where the average precipitation (Figs. 2-3) decreases. The inter-model spread is considerably larger in summer than in winter, illustrating the greater influence of local processes in this season; it should be noted 
25th percentile
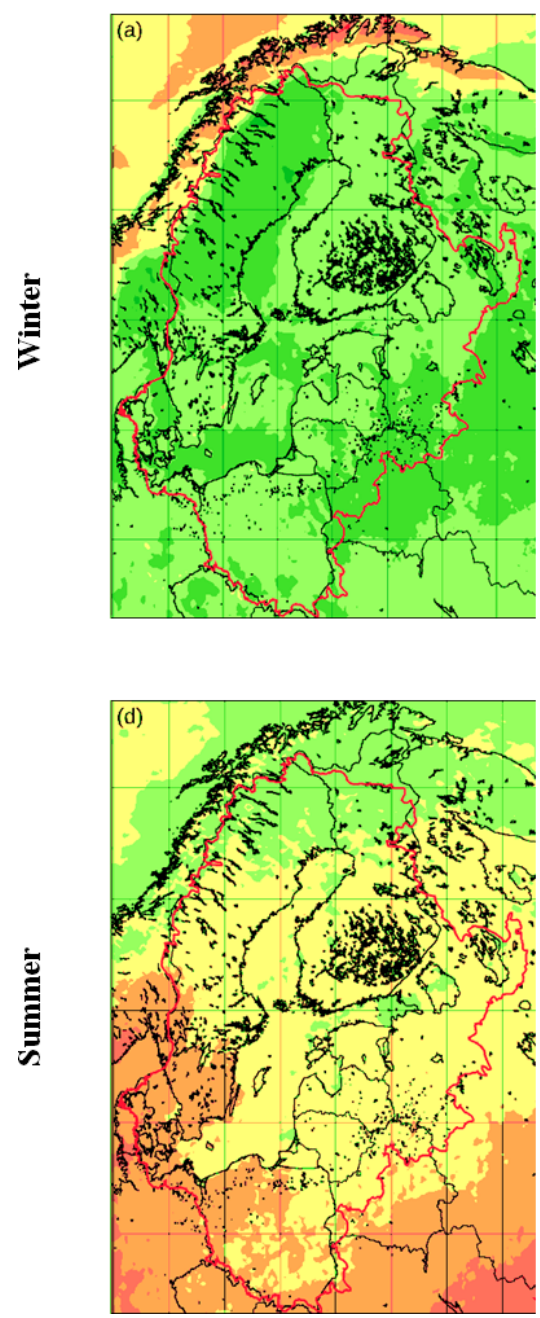

Median
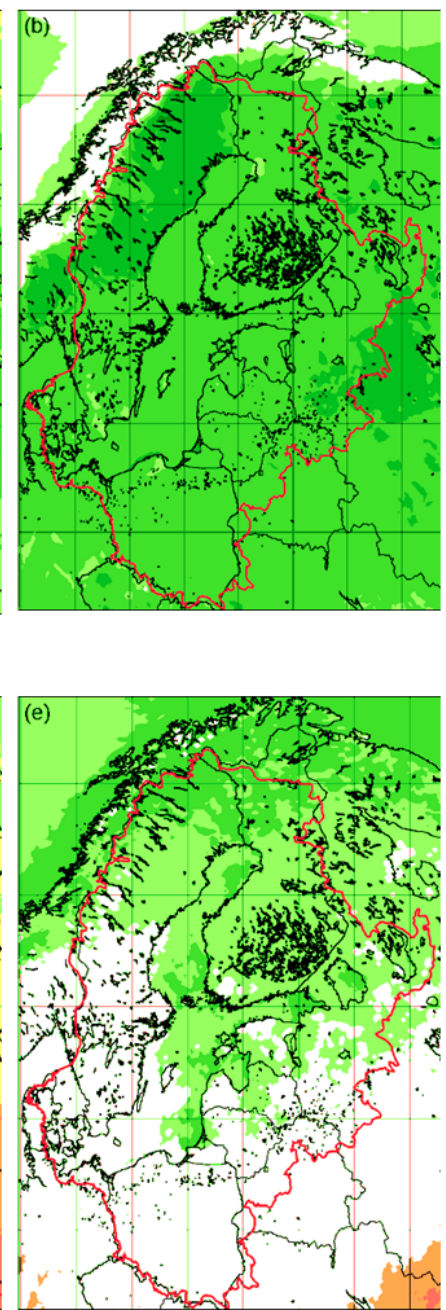

75th percentile
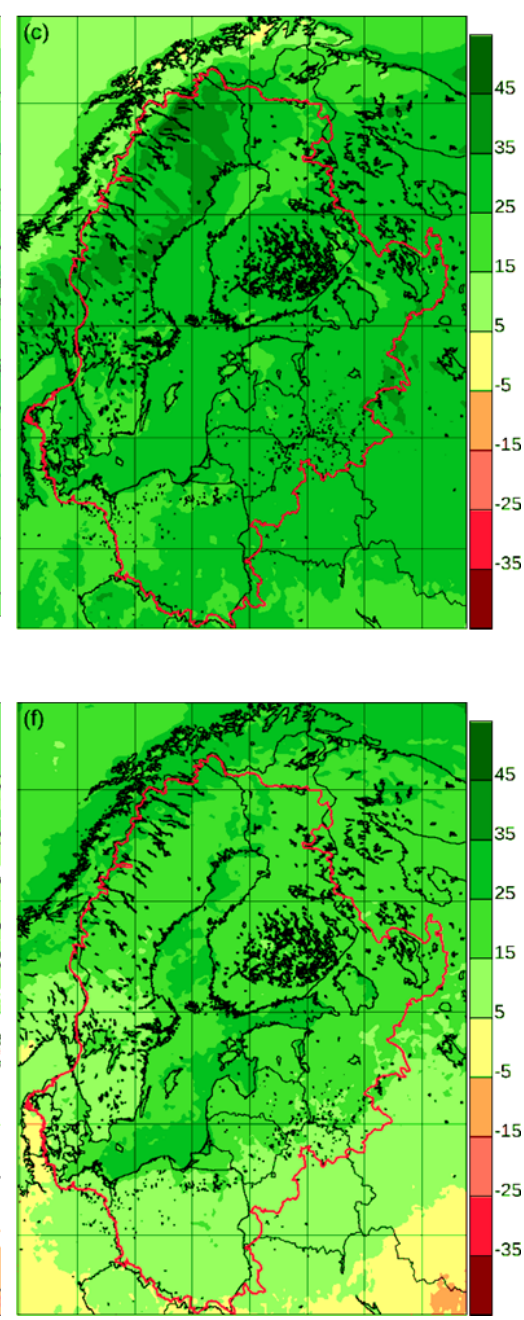

Figure 2. Precipitation relative change (\%) between 1981-2010 and 2071-2100 for 72 simulations from EURO-CORDEX according to the RCP8.5 scenario. (a-c) Winter. (d-f) Summer. (a, d) Lowest quartile; (b, e) median value; (c, f) higher quartile. In all following figures, panels $(\mathbf{b}, \mathbf{e})$ depicting pointwise median values are only coloured when $75 \%$ of simulations agree on the sign of the change. The Baltic Sea catchment is indicated in red.

that the increase from 19 to 90 in the number of models analysed, compared to Christensen and Kjellström (2018), results in a considerably more robust positive signal in the summer 10 -year return value.

The relative changes of extreme precipitation in winter (Fig. 4 upper panels) are quite similar to the relative change in average precipitation (Fig. 2), indicating no change in the shape of the intensity distribution function. For summer, however, the projected change in extreme precipitation is consistently more positive than the change in average precipitation. While the temperature sensitivities (slopes in Figs. 3 and 4) for winter average precipitation and winter extreme precipitation are almost identical, the sensitivity of extremes in summer is larger than that for winter, while it is insignifi- cant for the average precipitation in summer. This feature is, however, less apparent in the EURO-CORDEX results than in the PRUDENCE results of BACC (BACC Author Team, 2008) and the ENSEMBLES results described in BACC II (BACC II Author Team, 2015). It is not clear if this difference is due to the fact that the RCMs are run at different horizontal resolutions in the three projects (i.e. 50, 25, and $12.5 \mathrm{~km}$, respectively), or if it is a consequence of different model formulations in the projects or of the large-scale climate change signal as imposed by the underlying GCMs that also differs between the experiments.

Recently, several research institutes have started employing convection-permitting regional models (CPMs). Such models are able to run in much higher resolution, where tra- 

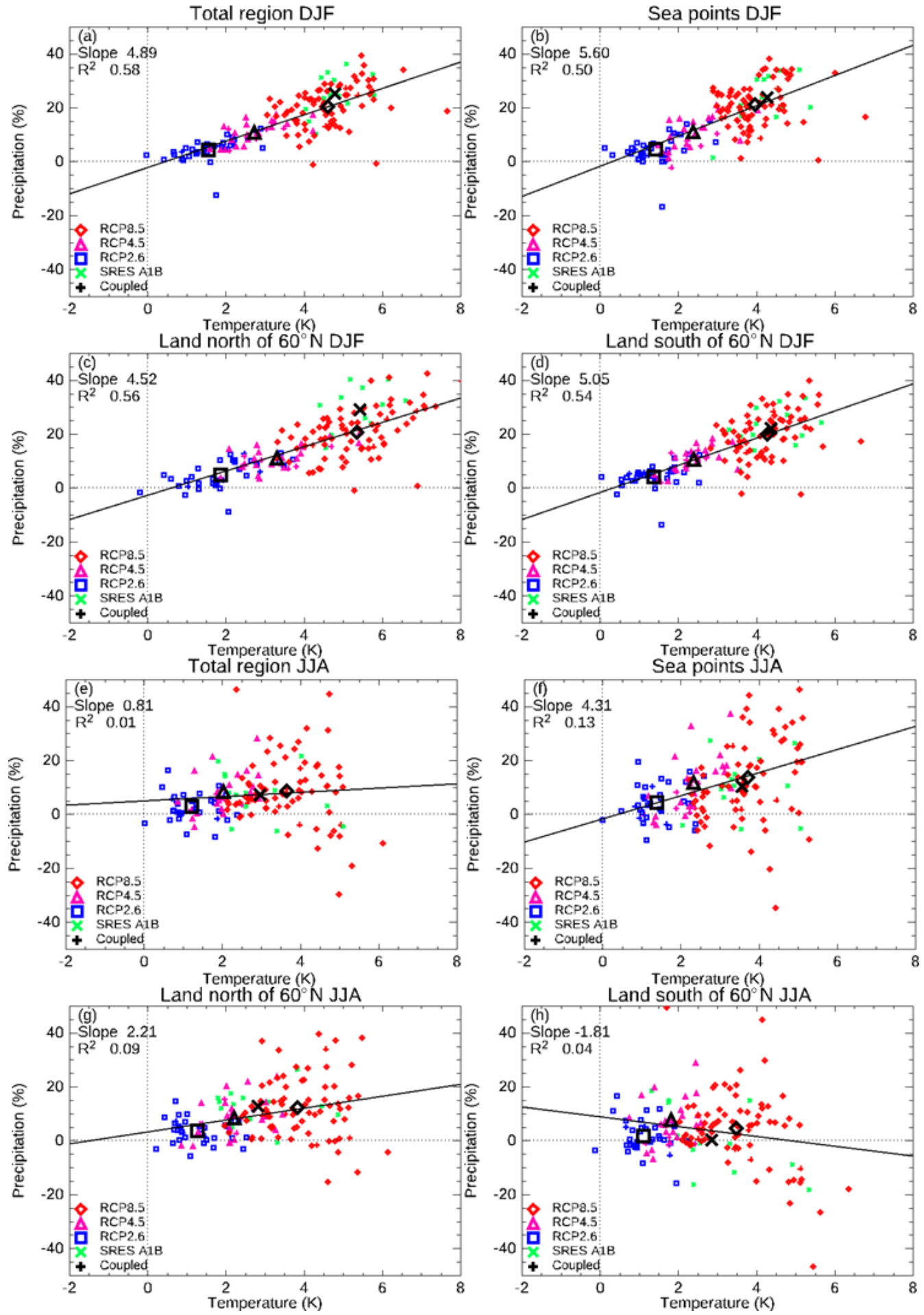

Figure 3. Relative change 1981-2010 to 2071-2100 of precipitation against temperature change for individual models and all scenarios. Scenario means are indicated by larger black symbols. Blue squares: RCP2.6; pink triangles: RCP4.5; red diamonds: RCP8.5; green crosses: the ENSEMBLES simulations analysed in BACC II (2015). Plus signs in colours corresponding to the scenario: the RCA4-NEMO atmosphereocean coupled simulations. Calculation performed for subsets of the Baltic catchment: the entire catchment; sea points; land points north and south of $60^{\circ} \mathrm{N}$, respectively. Panels (a)-(d) show winter; panels (e)-(h) show summer. The lines, with quoted slope and squared correlation coefficient, are best fits to all EURO-CORDEX and ENSEMBLES data but do not include coupled-model results. 
ditional hydrostatic RCMs with fully parameterized convective precipitation release may produce convective precipitation explicitly as well as parameterized, CPMs avoid this possible double counting at high resolution. With CPMs grid distances below the "grey zone" of 3-5 km are possible. In Lind et al. (2020), results are presented with the CPM HIRLAM ALADIN Regional Mesoscale Operational NWP in Europe Climate version (HARMONIE-Climate; HCLIM), produced in a common Nordic model collaboration (NorCP) with participation from Sweden, Norway, Denmark, and Finland. Comparing a CPM version of HCLIM in $3 \mathrm{~km}$ resolution with a non-CPM version in $12 \mathrm{~km}$, it was concluded that the high-resolution model showed better results for precipitation intensity distribution, including extreme precipitation at subdaily timescales, for the summer precipitation diurnal cycle, and for snow in mountains. Such better agreement now shown for the Nordic region has previously been shown for other regions in Europe and elsewhere (e.g. Kendon et al., 2014; Lind et al., 2016; Gao et al., 2020).

Based on convection-permitting models, it has been argued that changes in precipitation extremes of a shorter duration may be larger than those for longer timescales (e.g. Kendon et al., 2014; Lenderink and van Meijgaard, 2010). However, other results indicate (Ban et al., 2015) that convection-permitting models may give roughly the same increase also for shorter durations, consistent with the Clausius-Clapeyron scaling of around 6\%-7\% per degree of warming. In a study of idealized warming experiments repeating present-day observed weather under warmer and moister conditions with the HCLIM model, Lenderink et al. (2019) showed that the increase in precipitation extremes is strongly dependent on moisture availability.

\subsection{Wind speed}

Changes in the climatology of $10 \mathrm{~m}$ wind speed are even more uncertain than is the case for the precipitation climate, both for seasonal mean conditions and for extremes on shorter timescales (e.g. Kjellström et al., 2011, 2018; Nikulin et al., 2011).

In a study by Donat et al. (2011), annual 98th percentile daily maximum wind speed changes in RCM simulations from the ENSEMBLES project were analysed, for the middle of the century as well as the end of the century. The ensemble average, like the driving GCMs, increased in a region from the British Isles to the Baltic Sea and decreased in the Mediterranean area. Nikulin et al. (2011) found increasing wind speed extremes (20-year return periods of annual maximum $10 \mathrm{~m}$ wind speed) over the Baltic Sea in five out of six simulations, based on an ensemble of one RCM downscaling six different GCMs under the A1B scenario.

In BACC II (BACC II Author Team, 2015), an analysis of 13 ENSEMBLES simulations showed a very small insignificant median increase in the southern part of the Baltic Sea area; the signal is consistent with the findings by Donat et al. (2011) but with a large spread between models.

Figure 5 shows average changes over the Baltic Sea for the 72 EURO-CORDEX RCP8.5 simulations, the 22 RCP4.5 simulations, and the 30 RCP2.6 simulations, which were used (Table 1). In Figs. S13-S18, we show median and quartile maps for summer and winter for each of the three RCP scenarios. There is very little agreement between the models about even the direction of change for winter in the Baltic Sea area unlike the tendency for reduced average wind speed outside of the study area over the North Atlantic (not shown). Over the northernmost part of the Baltic Sea basin, the Bothnian Bay, there is an indication of larger wind speed increase (or less decrease) over the sea than over surrounding land areas. This feature has previously been pointed out by Kjellström et al. (2011), Meier et al. (2011), and Tobin et al. (2016), and has been related to decreases in sea ice in the future warmer climate, leading to consequent changes in stability conditions of the lower atmosphere. See also the comparison between regional coupled and uncoupled simulations in Fig. 12, where the probably more consistent treatment of ice-albedo feedback leads to a slightly larger increase in winter. As seen in Fig. 5b, the slight increase in mean wind over the Baltic Sea in BACC II is not projected in the current simulations.

Summer results show consistent but small reductions of wind over land of about $2 \%-6 \%$. Again, in summer, there are differences between land and ocean areas with generally larger increases, or smaller decreases, over the Baltic Sea than its surrounding land areas.

The relative change in extreme wind speed is shown in Fig. 6 as the relative change of the 10-year return value of daily maximum wind speed for the EURO-CORDEX RCPbased and the BACC II SRES-based simulations considered, as well as for the coupled RCA4-NEMO simulations. The correlation between temperature and extreme wind is quite small, which indicates that there is no significant signal.

\subsection{Solar irradiation}

In Fig. 7, we study the change in incoming solar radiation in the ensemble. In winter, most of the area shows a considerable relative reduction of the order of $10 \%$. This has been proposed to be linked to the more extensive cloud cover in northern Europe in most EURO-CORDEX RCMs for the future (Coppola et al., 2021). It should be noted (Bartók et al., 2017) that global and regional models frequently disagree considerably about the change in incoming radiation in a changing climate, with global models having a more positive trend; this discrepancy is connected to different projections of cloud cover, with GCMs frequently projecting a decrease, while RCMs frequently show no significant change. We repeat here that the different treatment of aerosols in GCMs and RCMs plays a role as many of the RCMs do not include time-varying anthropogenic aerosols as in GCMs 

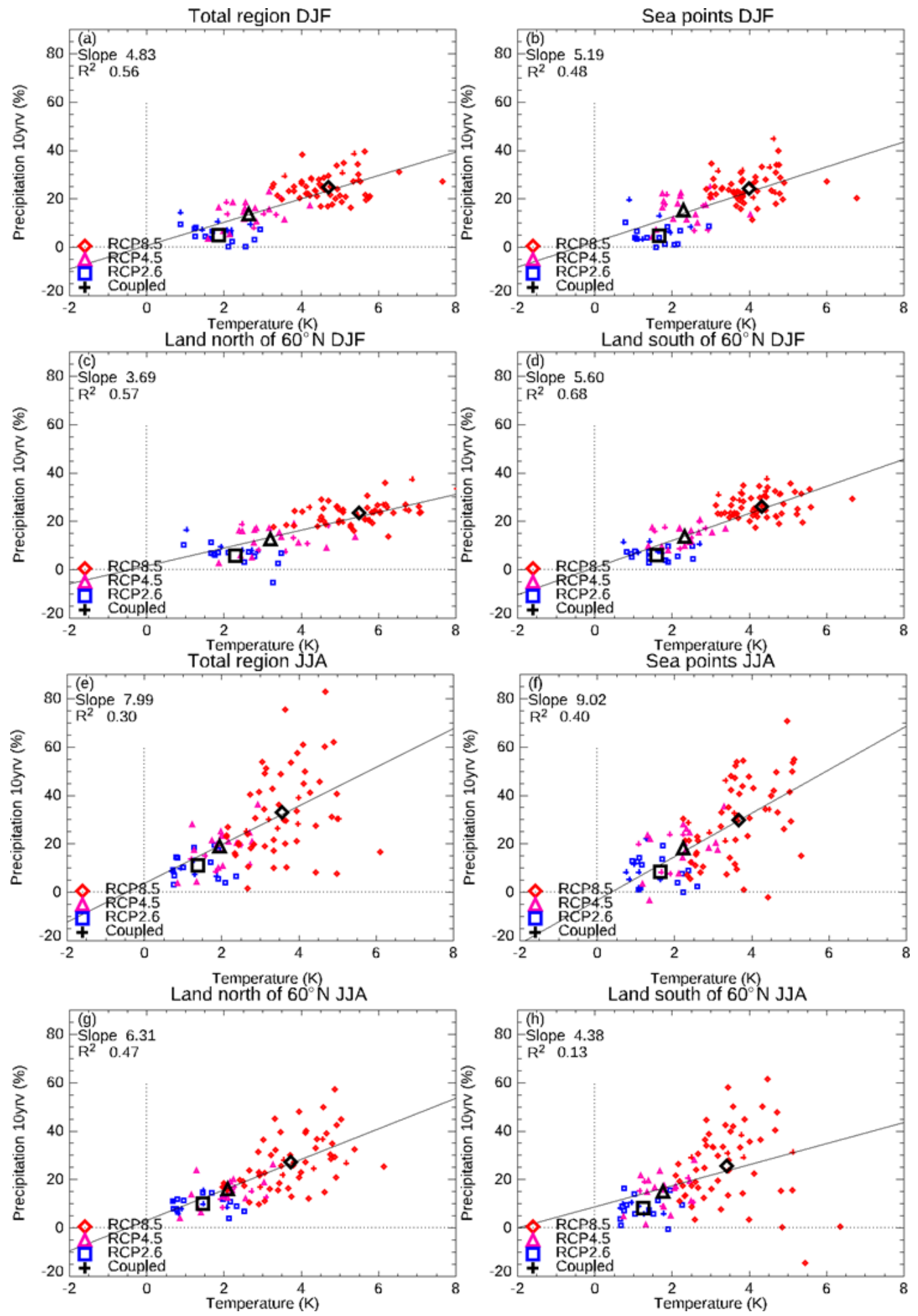

Figure 4. Relative change 1981-2010 to 2071-2100 of the 10-year return value of daily precipitation against temperature change for individual models and all scenarios. Scenario means are indicated by larger black symbols. Blue squares: RCP2.6; pink triangles: RCP4.5; red diamonds: RCP8.5; green crosses: the ENSEMBLES simulations analysed in BACC II (2015). Plus signs in colours corresponding to the scenario: the RCA4-NEMO atmosphere-ocean coupled simulations. Calculation performed for subsets of the Baltic catchment: the entire catchment; sea points; land points north and south of $60^{\circ} \mathrm{N}$, respectively. Panels (a)-(d) show winter; panels (e)-(h) show summer. The lines, with quoted slope and squared correlation coefficient, are best fits to all EURO-CORDEX and ENSEMBLES data but do not include coupled-model results. 

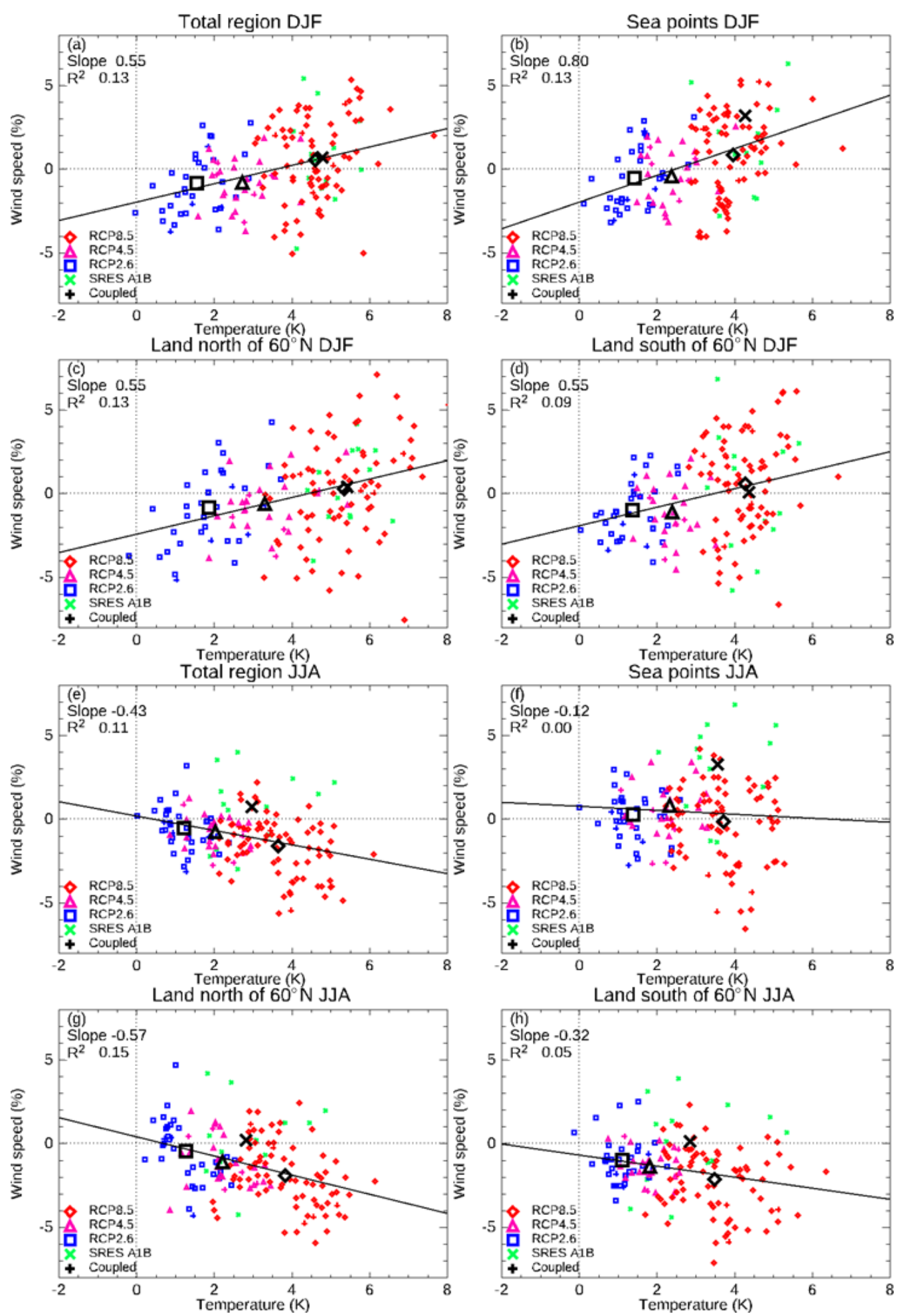

Figure 5. Relative change 1981-2010 to 2071-2100 of 10 m wind speed against temperature change for individual models and all scenarios. Scenario means are indicated by larger black symbols. Blue squares: RCP2.6; pink triangles: RCP4.5; red diamonds: RCP8.5; green crosses: the ENSEMBLES simulations analysed in BACC II (2015). Plus signs in colours corresponding to the scenario: the RCA4-NEMO atmosphere-ocean coupled simulations. Calculation performed for subsets of the Baltic catchment: the entire catchment; sea points; land points north and south of $60^{\circ} \mathrm{N}$, respectively. Panels (a-d) show winter; panels (e-h) show summer. The lines, with quoted slope and squared correlation coefficient, are best fits to all EURO-CORDEX and ENSEMBLES data but do not include coupled-model results. 

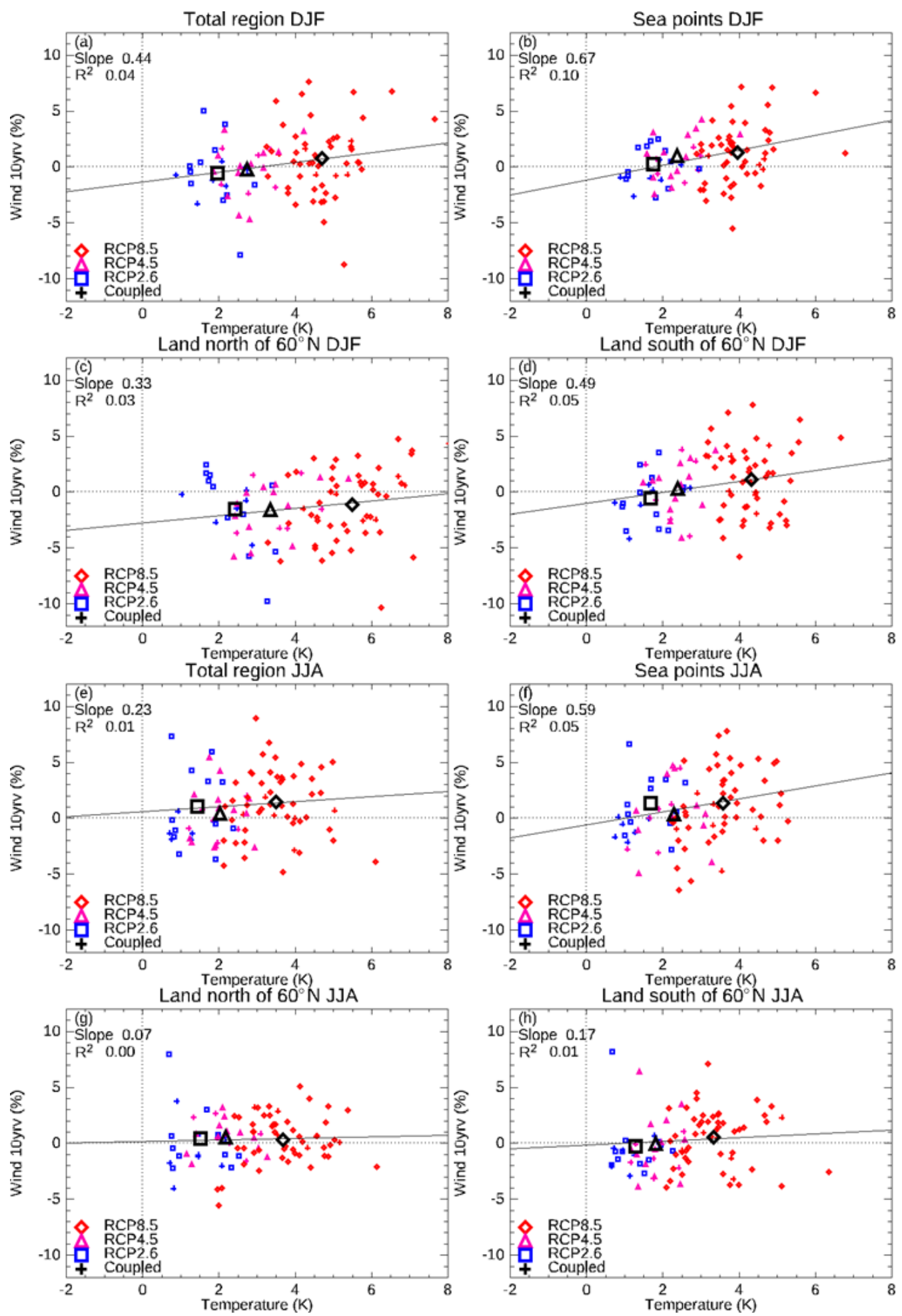

Figure 6. Relative change 1981-2010 to 2071-2100 of the 10-year return value of $10 \mathrm{~m}$ daily maximum wind speed against temperature change for individual models and all scenarios. Scenario means are indicated by larger black symbols. Blue squares: RCP2.6; pink triangles: RCP4.5; red diamonds: RCP8.5; green crosses: the ENSEMBLES simulations analysed in BACC II (2015). Plus signs in colours corresponding to the scenario: the RCA4-NEMO atmosphere-ocean coupled simulations. Calculation performed for subsets of the Baltic catchment: the entire catchment; sea points; land points north and south of $60^{\circ} \mathrm{N}$, respectively. Panels (a)-(d) show winter; panels (e)-(h) show summer. The lines, with quoted slope and squared correlation coefficient, are best fits to all EURO-CORDEX and ENSEMBLES data but do not include coupled-model results. 
25th percentile
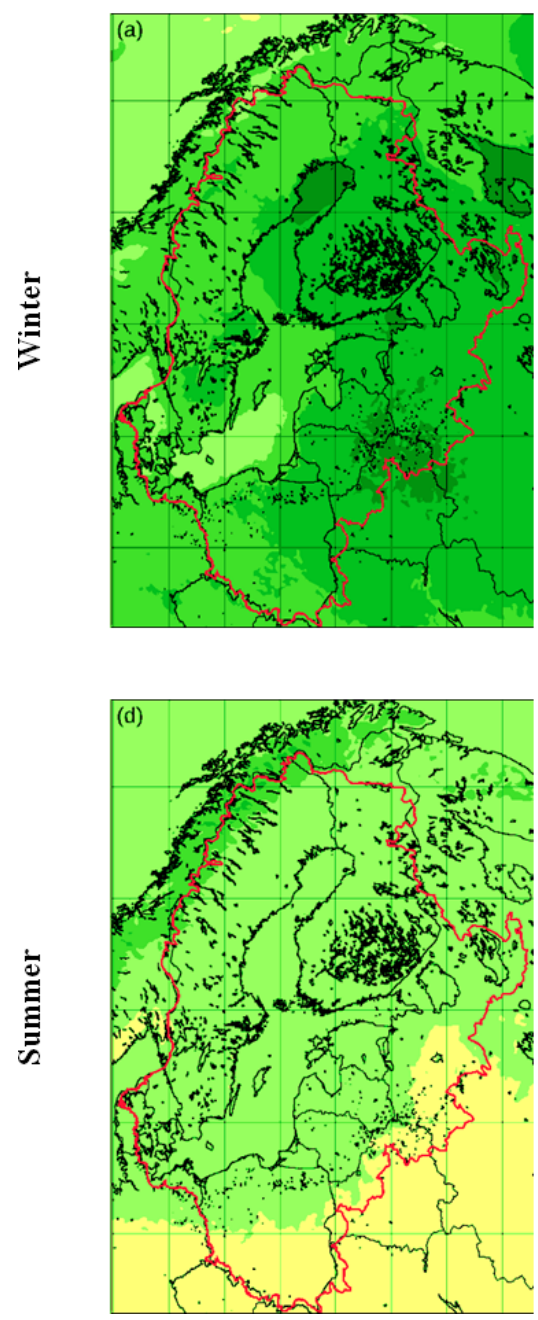

Median
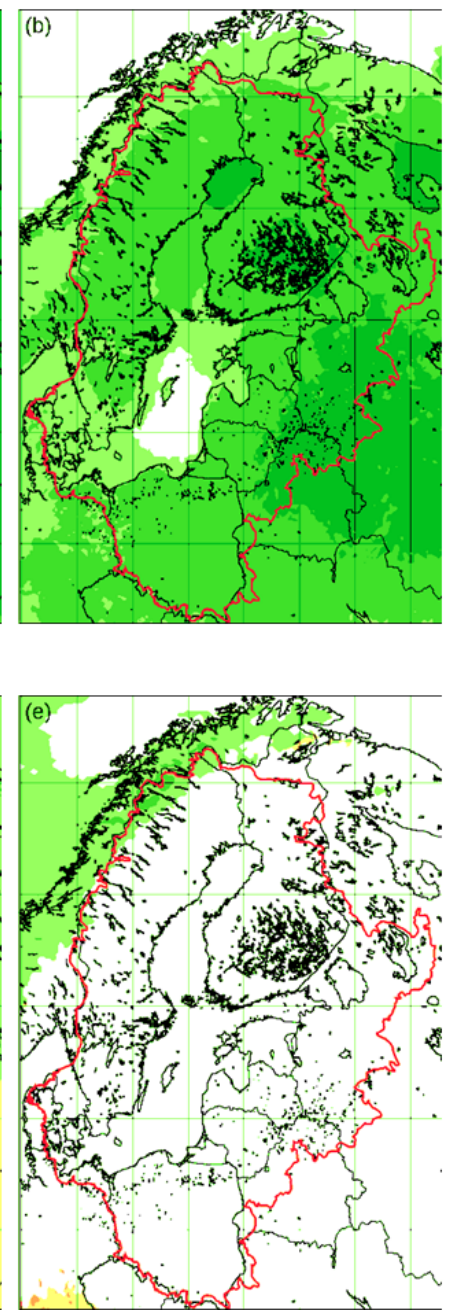

75th percentile
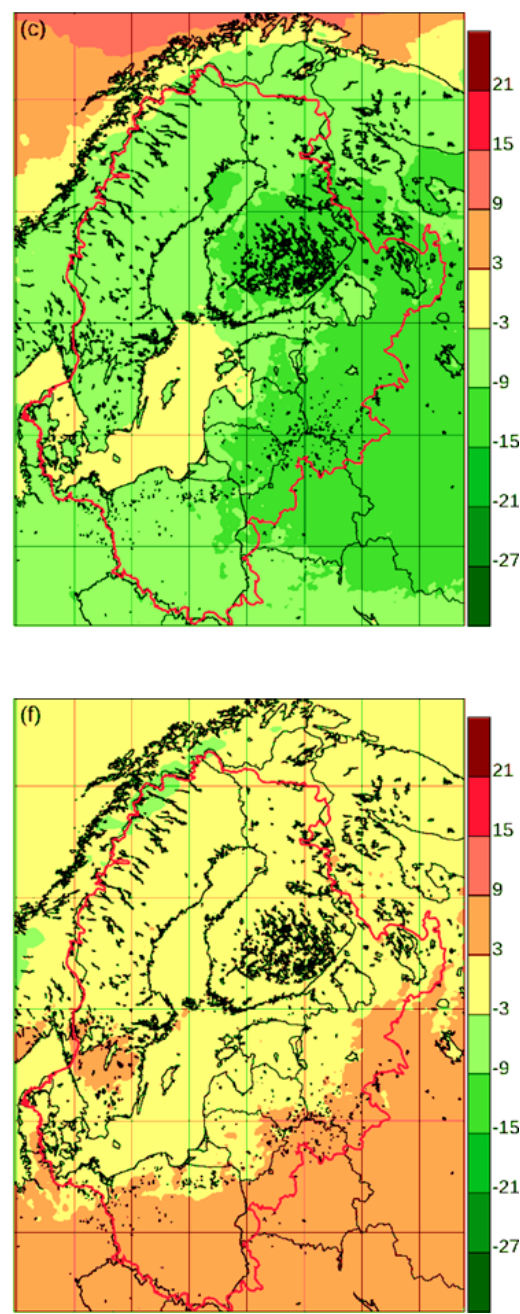

Figure 7. Average incoming surface solar radiation relative change between 1981-2010 and 2071-2100 for 70 simulations from EUROCORDEX according to the RCP8.5 scenario. (a-c) Winter; (d-f) summer. (a, d) Lowest quartile; (b, e) median value; (c, f) higher quartile. For the medians, only points where $75 \%$ of models agree on the sign are shown. The Baltic Sea catchment is indicated in white.

(Boé et al., 2020). It has also been suggested that reduced snow cover (see Sect. 3.6 below) could contribute to attenuate gross downward solar radiation flux as the reduced surface albedo reduces multiple reflection between the surface and the clouds (Ruosteenoja and Räisänen, 2013).

\subsection{Snow and sea ice}

Future snow cover is expected to decrease with climate warming, both because more precipitation is projected to fall as rain, and because snowmelt accelerates. As an indicator of less cold conditions, Coppola et al. (2021) show that the number of frost days decrease by more than 2 months in large parts of the Baltic Sea basin comparing a set of EUROCORDEX RCMs under RCP8.5 for 2071-2100 with 1981-
2010. Simultaneously, there is an increase in winter precipitation in Scandinavia, which may partly compensate for these effects.

Räisänen and Eklund (2011) analysed data from RCM simulations from the ENSEMBLES project. The study found a decrease of snow volume across all of Europe in the future with the only exception that the Scandinavian mountain areas may experience a slight and statistically insignificant increase. Räisänen (2021) found a widespread future decrease in northern Europe for snow water equivalents also for a set of EURO-CORDEX RCMs. It was shown that a smaller snowfall fraction together with larger reduction of snow on the ground more than compensated for increasing precipitation, as seen in several of the RCMs. In relative numbers, the decrease was found to be larger in southern 

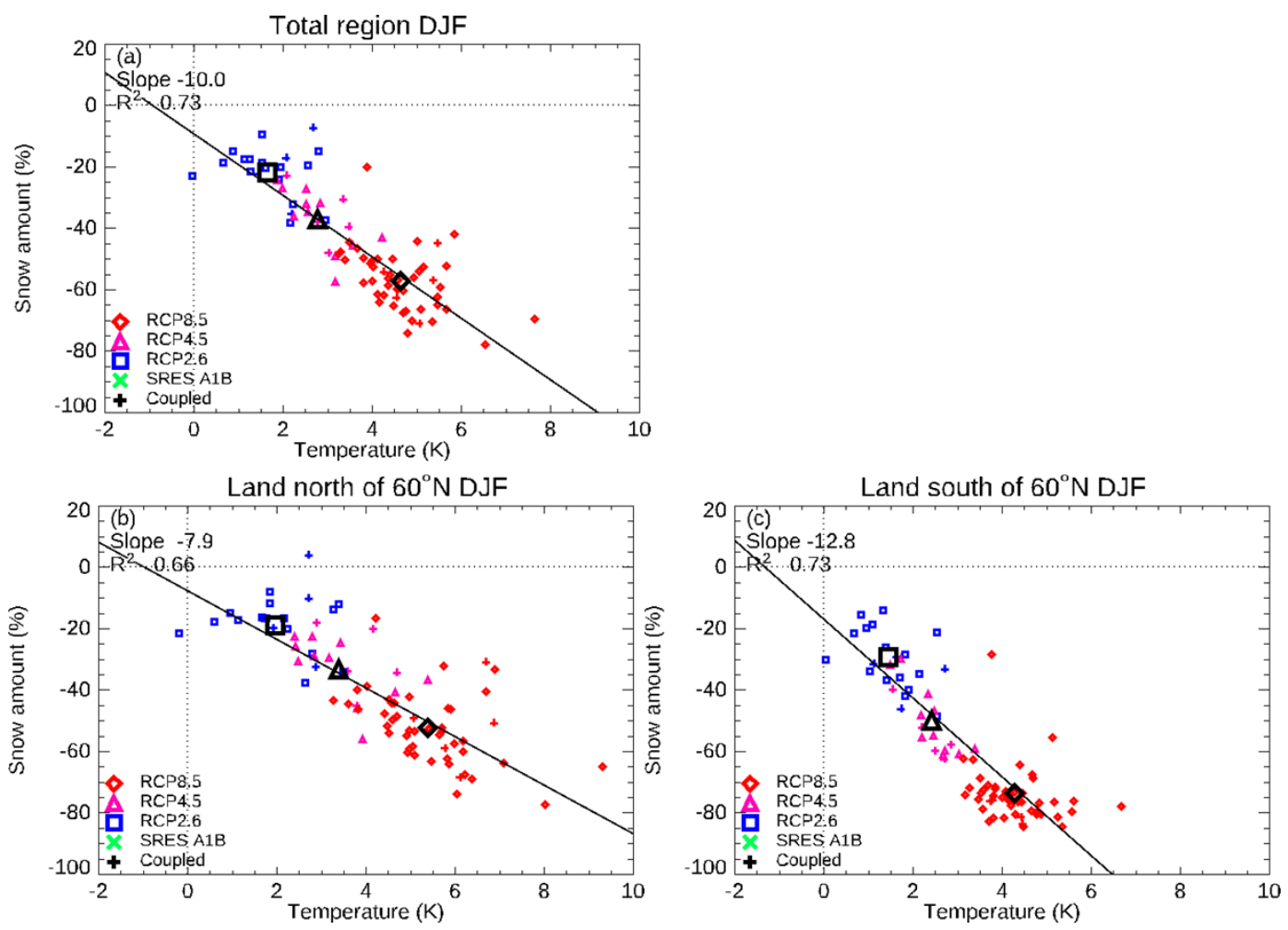

Figure 8. Relative change 1981-2010 to 2071-2100 of average winter (DJF) snow amount (kg/m²) against temperature change for 84 individual model simulations from all scenarios. Scenario means are indicated by larger symbols. Squares: RCP2.6; triangles: RCP4.5; diamonds: RCP8.5. Purple colour: the RCA4-NEMO atmosphere-ocean coupled simulations. Calculation performed for subsets of land points in the Baltic catchment: the entire catchment; land points north and south of $60^{\circ} \mathrm{N}$, respectively. The lines, with quoted slope and squared correlation coefficient, are best fits to all EURO-CORDEX data but do not include coupled-model results.

warmer parts of Scandinavia, while changes in absolute numbers are larger in the north. Similarly, the results were ambiguous for the most high-altitude parts of the Scandinavian mountains where some models indicate increasing snow water and others a decrease. A potential increase in the latter region was also proposed by Schuler et al. (2006) in a detailed study for Norway based on two RCM simulations with different GCM drivers. The study concluded that the maximum amount of snow in extreme years could be greater than in extreme years of the recent past in spite of decreasing average snow amount.

Winter snow cover is one of the most drastically changed climatological quantities (Fig. 8). There is agreement between models about a reduction of average wintertime snow amount of around $50 \%$ on average for land grid points north of $60^{\circ} \mathrm{N}$ for the RCP8.5 scenario, and almost $80 \%$ reduction for land grid points south of this latitude. Northern grid points probably have a lower reduction due to the generally colder climate and smaller amount of solar radiation. In addition, there is a significant amount of mountain grid points, where the warming temperature does not reach the freezing point as frequently as in lower-lying regions even if the frequency is increasing in a warmer climate (Nilsen et al.,
2021). The reduction in snow amount is slightly larger than in BACC II (BACC II Author Team, 2015). This is consistent both with the fact that the RCP8.5 scenario on average projects larger warming than the SRES A1B scenario used in BACC II and that the precipitation increase is smaller in the RCP8.5 scenario than in SRES A1B, at least north of $60^{\circ} \mathrm{N}$ (see Fig. 3c).

It is only in high-altitude parts of central and northern Scandinavia that changes are limited with relatively large amounts of snow also in the future. At high altitude, the increase of winter precipitation may be compensating for the increase in melting with higher temperature. Also the fact that increasing temperatures may not reach the melting point is significant; see, e.g. Gröger et al. (2021a) Fig. 12b. However, also in these high-altitude regions, the warmer future climate results in a shorter snow season with accumulation starting later and spring melt starting earlier, which acts to reduce the total amount of snow (Räisänen, 2021).

Sea-ice cover is not a product of the RCM but rather an input originating from the driving GCM. We will show the changes in interpolated sea-ice field for the RCP8.5 scenario in Fig. 9, as these changes are large and are decisive for the change in climate between the periods. In order to compare 
25th percentile
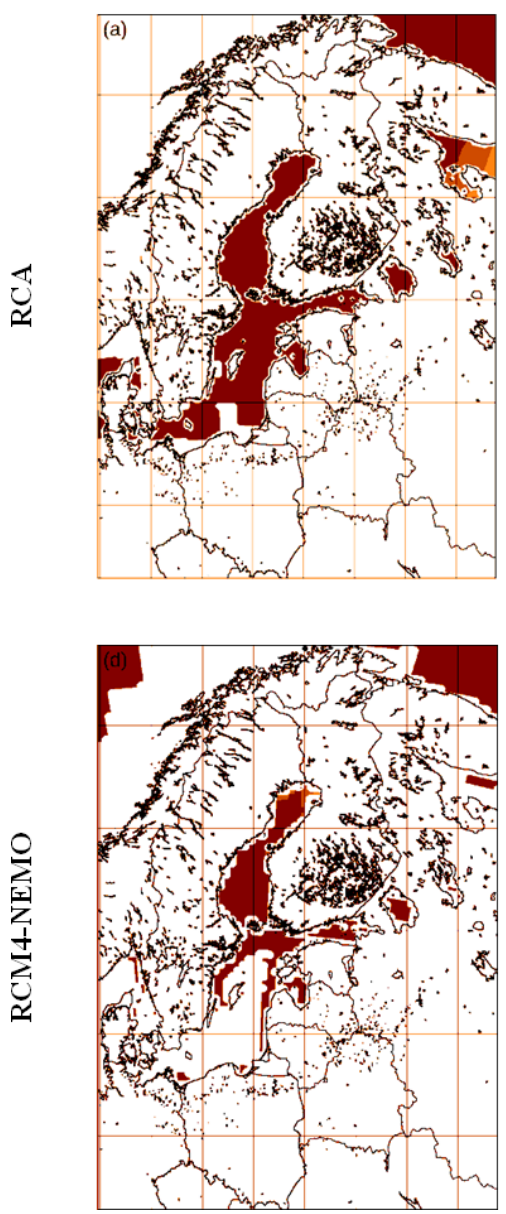

Median
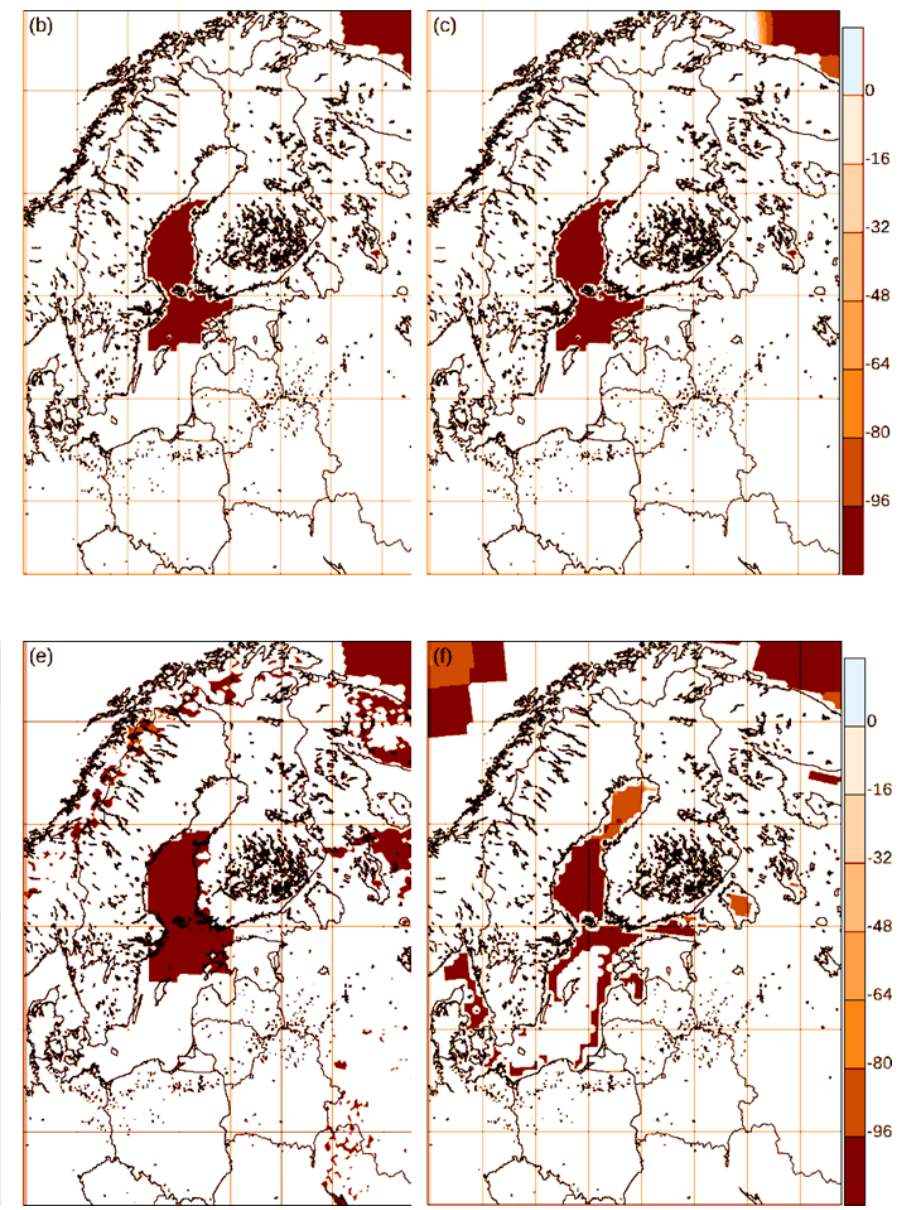

Figure 9. (a-c) Average winter sea-ice cover relative change between 1981-2010 and 2071-2100 for the simulations from EURO-CORDEX according to the RCP8.5 scenario driven by the GCMs where RCA4-NEMO simulations exist. These values have been interpolated before the RCM simulations from the driving coupled GCM; note that several simulations have sea ice in the Baltic Sea in the present-day period but not in the Bothnian Bay. For comparison, in panels (d-f), we also show the corresponding fields from the corresponding five coupled RCA4-NEMO simulations where sea-ice cover is calculated inside the regional model. (a, d) Lowest quartile; (b, e) median value; (c, f) higher quartile. For the medians, only points where $75 \%$ of models agree on the sign are shown.

to a more consistent description of sea ice, we also show in Fig. 10 the corresponding figures for the eight-member RCA4-NEMO coupled regional simulations. The main difference is that the present-day simulations with the coupled model have some extent of coastal sea ice in the southern Baltic Sea, which is disappearing in the future.

\section{Effects of model coupling}

Here, we take a more detailed look at RCM simulations driven by the five GCMs, which have been downscaled both by the stand-alone atmosphere EURO-CORDEX ensemble and by the $24 \mathrm{~km}$ RCA4-NEMO coupled-model version (all coloured squares in Table 1 for the RCA4 RCM).
For near-surface air temperature (Fig. 10), the large-scale anomaly pattern is fairly coherent in the two ensembles but differences are found over the northern Baltic Sea where the coupled model shows a systematically stronger winter warming than the uncoupled model. Over land, the coupled model displays systematically lower warming. By contrast, during summer the coupled model shows a weaker warming over the entire Baltic Sea, while land temperatures increase more than in the stand-alone RCA.

Due to its higher effective heat capacity, the Baltic Sea acts as a thermal buffer, which dampens the seasonal amplitude compared to the surrounding land areas. As a result, the Baltic Sea is warmer than the overlying atmosphere during winter and releases heat to the atmosphere. Hence, in regions not covered by sea ice, the SST significantly influ- 

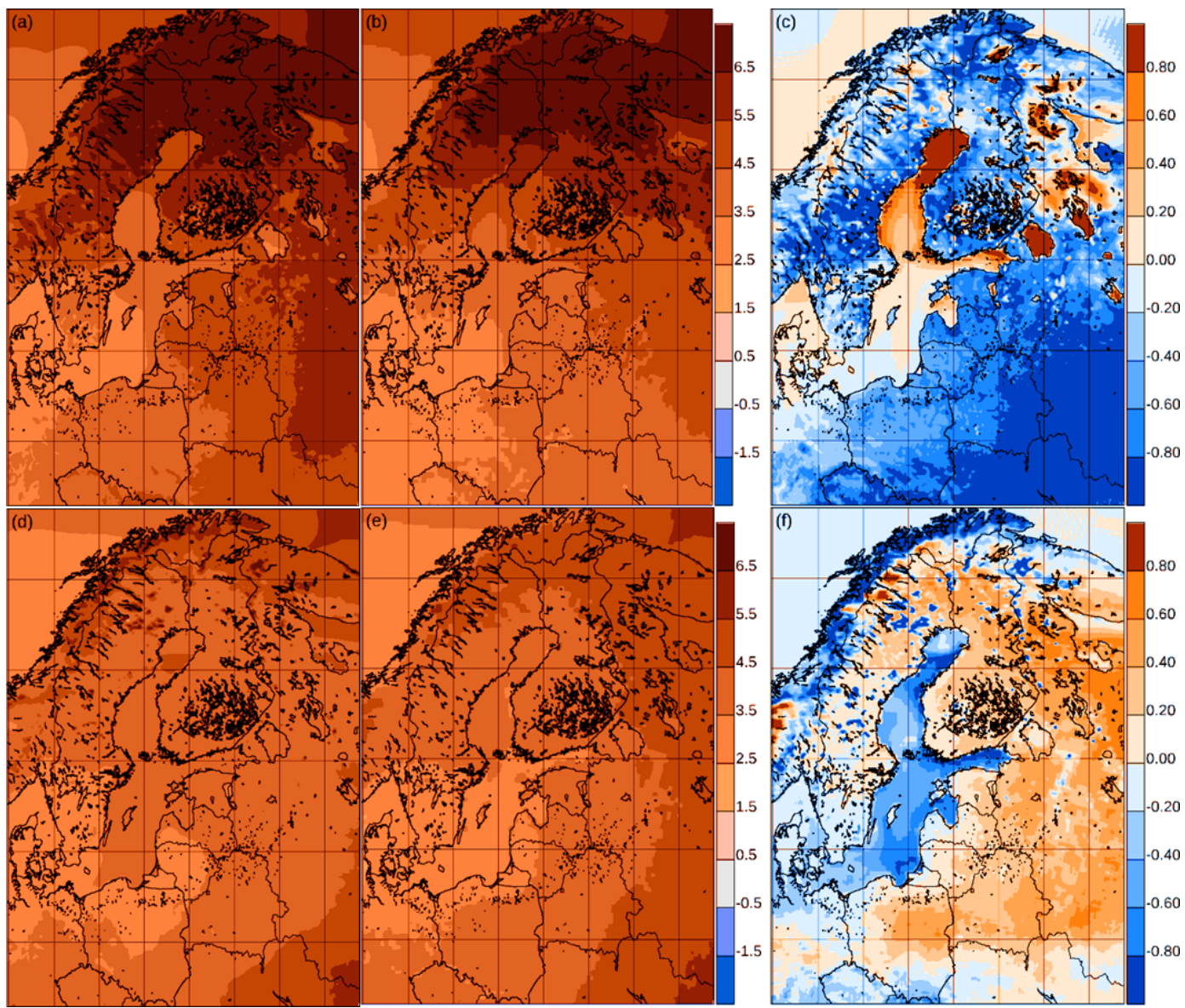

Figure 10. Temperature change between 1981-2010 and 2071-2100 for five atmosphere-only RCA4 simulations from EURO-CORDEX according to the RCP8.5 scenario (a, d) and for the coupled single-model RCA4-NEMO ensemble with the same driving GCMs (b, e); pointwise median values, only coloured when $75 \%$ of simulations agree on the sign of the change. Difference between the two (c, $\mathbf{f} ;$ coupled minus uncoupled; $\left.{ }^{\circ} \mathrm{C}\right)$. (a-c) Winter; (d-f) summer.

ences the sea-to-air heat flux. Consequently, in the uncoupled model, the prescribed SSTs from the driving atmosphereocean GCM (AOGCM) serve as a restoring term for the air temperature. By contrast, in the coupled model, SSTs are simultaneously modelled by the ocean model and so the airto-sea heat transfer acts to cool SSTs until a new equilibrium would be reached. Despite these different dynamics in thermal coupling, over the southern Baltic Sea, the solution of the two models is quite similar compared to the northern Baltic (Fig. 10).

In the northern Baltic Sea, the reduction of sea ice has to be considered. In the future climate, areas which today are covered by sea ice will get more tightly thermally coupled to the water body of the Baltic Sea (Dutheil et al., 2022). As shown by Gröger et al. (2015, 2021a, b), the ocean-to-atmosphere heat transfer is largely affected by small-scale vertical mixing in the layered ocean because wind-induced mixing transports warm waters from deeper water layers to the surface. These small-scale processes are most likely not well represented in the prescribed SST from the driving global ocean
GCM. Furthermore, changes in the mean and turbulent wind stress due to local climate change in RCA have no impact on wind-induced mixing in the ocean in the RCA stand-alone simulations. This further influences the local sea-ice cover and thus may explain the stronger warming over the northern Baltic Sea in the coupled model compared to the uncoupled version of RCA, which according to Fig. 9 generally starts out with less sea ice in the present-day period and therefore experiences less sea-ice loss. In the atmosphere, a stronger thermal coupling to the water body not only changes nearsurface temperatures but also modifies atmospheric stability and thereby mixing of heat, moisture, and momentum with potential impacts on temperature, precipitation, and winds.

During summer when the Baltic Sea takes up heat from the atmosphere, the air-sea heat exchange is greatly influenced by the water bodies' thermocline layer, which is of the order of 10-30 m thick (e.g. Gröger et al., 2019). Thermocline dynamics is likely much more realistically represented when explicitly modelled by a coupled high-resolution ocean RCM rather than reflected in prescribed SST taken from a 

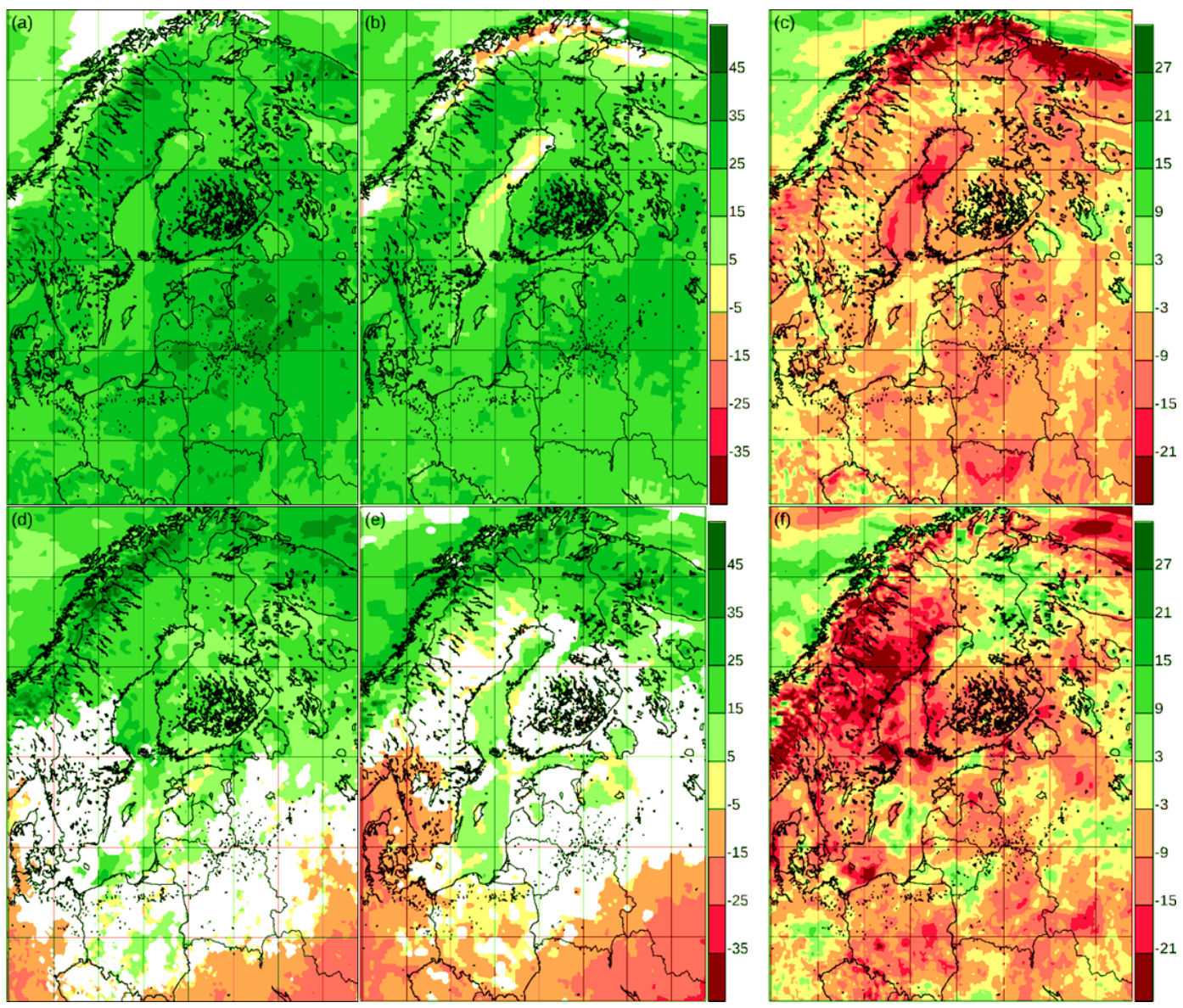

Figure 11. Precipitation relative change (\%) between 1981-2010 and 2071-2100 for five atmosphere-only RCA4 simulations from EUROCORDEX according to the RCP8.5 scenario (a, d) and for the coupled single-model RCA4-NEMO ensemble with the same driving GCMs (c, f); pointwise median values, only coloured when $75 \%$ of simulations agree on the sign of the change. Difference between the two (c, f; coupled minus uncoupled; \%). (a-c) Winter; (d-f) summer.

global GCM of coarse resolution and only a few vertical layers (Gröger et al., 2015).

Winter precipitation (Fig. 11) displays a fairly coherent spatial pattern of change for the coupled and uncoupled RCA projections. However, the coupled model simulates systematically lower increases in precipitation than the uncoupled model. This is seen for both winter and summer. The differences are most prominent over western Scandinavia and the Bothnian Sea especially during summer.

A prominent feature of winter wind speed changes (Fig. 12) is the strong decrease along the Norwegian coast seen in the coupled RCA model. This is also notable but less pronounced in the uncoupled runs. However, in those regions with steep topographic gradients, the differences can be likely attributed to the differing grid resolutions though coupling effects cannot be excluded. For most other land regions, winds are slightly weakened in the lower and slightly strengthened in the higher quartile, and a consequently high uncertainty is seen for median winds (not shown). This is probably an effect of the different resolution of the two en- sembles. A noteworthy difference between coupled and uncoupled simulations during winter is the stronger increase in wind speeds over the Bothnian Bay. This points to local coupled feedback processes probably related to the vanishing sea ice, higher sea-surface temperatures, and altered atmospheric static stability. A larger decrease in sea ice and a stronger coupling between the atmosphere and the water body leads to a stronger heat flux to the atmosphere and thereby reduced vertical stability. This, in turn, leads to a more efficient downward mixing of momentum in the lower atmosphere and consequently higher wind speed close to the sea surface.

The changes between future and present climate conditions in solar irradiation (Fig. 13) are closely linked to changes in cloud cover. Both RCA versions simulate a generally less pronounced reduction in solar radiation during winter than the average reduction seen in the entire EUROCORDEX ensemble (Fig. 7). Strongest reductions are found over the Bothnian Bay in winter where vanishing sea ice exposes open water to the atmosphere formerly isolated by sea ice. Compared to the coupled version, the uncoupled RCA 

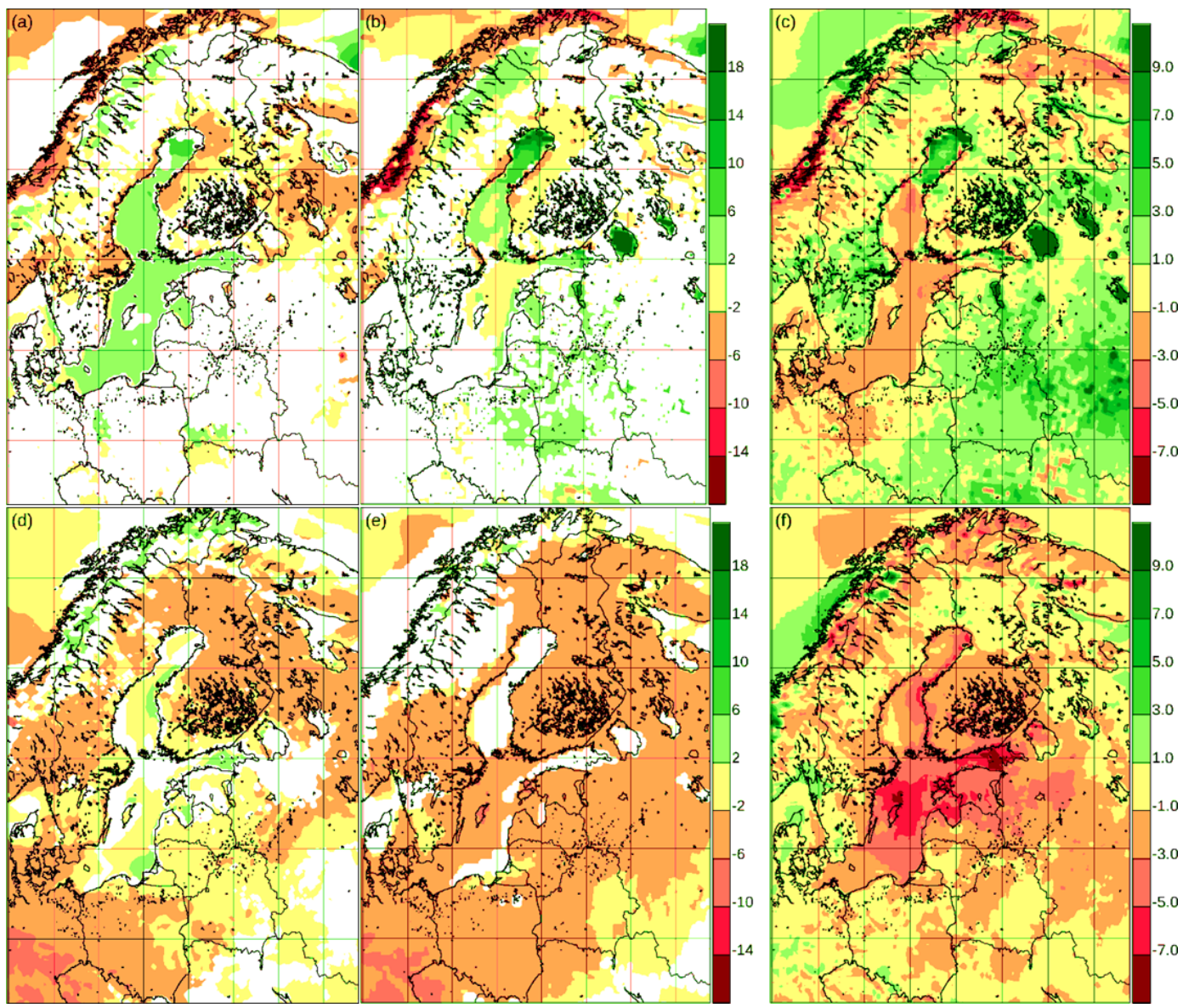

Figure 12. Average wind speed relative change (\%) between 1981-2010 and 2071-2100 for five atmosphere-only RCA4 simulations from EURO-CORDEX according to the RCP8.5 scenario (a, d) and for the coupled single-model RCA4-NEMO ensemble with the same driving GCMs (c, f); pointwise median values, only coloured when $75 \%$ of simulations agree on the sign of the change. Difference between the two (c, f; coupled minus uncoupled; \%). (a-c) Winter; (d-f) summer.

reveals a stronger reduction, in particular over the Bothnian Sea (Fig. 13).

To fully understand the different responses, detailed process analyses including the respective ocean dynamics would be necessary to draw general conclusions. In addition, the here-described systematic coupled vs. uncoupled differences may be specific with regard to the employed RCA regional atmosphere model and the coupled NEMO ocean RCM. Also, the atmospheric part of the model, RCA, is run with different resolutions in the coupled and uncoupled simulations, which may have an impact on the results. Hence, the here-found systematic differences should be tested in coordinated experiments also including those with other coupled and uncoupled systems.

Finally, we note that the coupling area comprising the North Sea and Baltic Sea only is relatively small compared to entire EURO-CORDEX domain, and there is indication that coupling effects may be more important if other seas, such as the Mediterranean or the NE Atlantic, are included (e.g. Kelemen et al., 2019; Primo et al., 2019; Akhtar et al.,
2019; Gröger et al., 2021b). The potential of different coupling techniques to influence the response of atmospheric large-scale circulation to climate change has been found to be most important during the winter season.

\section{Conclusions}

Since the previous BACC reports from 2008 and 2015, a very large amount of high-resolution regional climate model simulations have been performed over Europe, mostly downscaling global simulations from CMIP5. We have presented ensemble model results here, and we have compared the climate change results to those of BACC II (BACC II Author Team, 2015). The regional climate model simulations of BACC II were using a different emission scenario (SRES A1B) and a different set of GCMs than the currently used RCP scenarios from CMIP5. We have therefore chosen to compare the results as a function of local temperature change. 

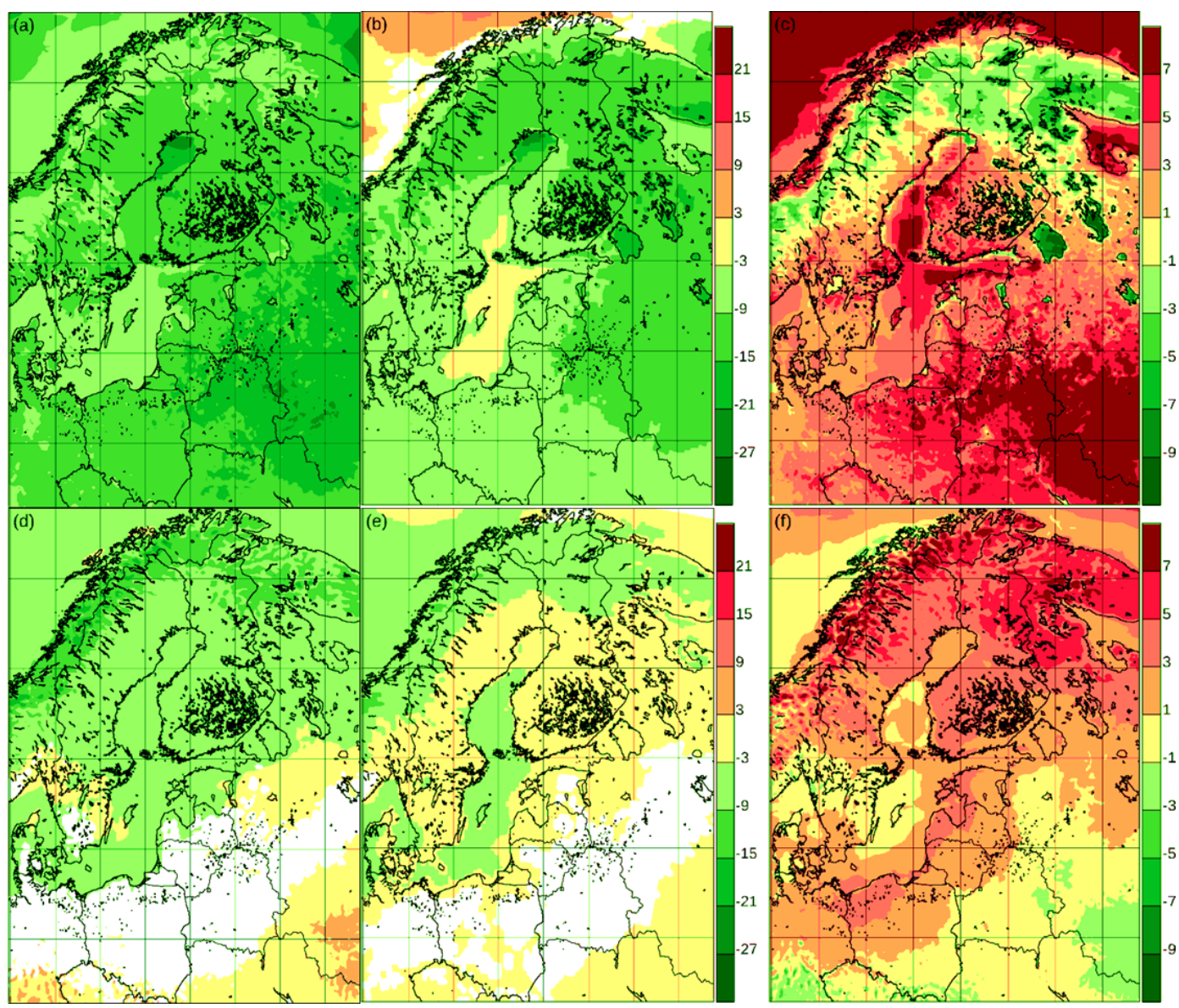

Figure 13. Average incoming solar radiation relative change (\%) between 1981-2010 and 2071-2100 for five atmosphere-only RCA4 simulations from EURO-CORDEX according to the RCP8.5 scenario (a, d) and for the coupled single-model RCA4-NEMO ensemble with the same driving GCMs (c, f); pointwise median values, only coloured when $75 \%$ of simulations agree on the sign of the change. Difference between the two (c, f; coupled minus uncoupled; \%). (a-c) Winter; $(\mathbf{d}-\mathbf{f})$ summer.

The results, illustrated for seasonal mean precipitation (Fig. 3) and wind speed (Fig. 5), do not indicate any significant change in the relation of these fields to local temperature change since BACC II. However, the much larger ensemble of scenario simulations allows for a more reliable assessment of future climate change compared to earlier studies. This is illustrated in the figures showing how the increase in the number of simulations, particularly the many more global models considered, has given much more robust estimates of uncertainty. This is the case both for local climate sensitivity, as illustrated by the different temperature change values for downscaling of each individual emission scenario, and for the intervariable relations, as illustrated with the general scatter of the points. Also, the addition of several emission scenarios enables a better foundation for estimating effects of, e.g. emission mitigation.

The local winter temperature increases of current RCP8.5 simulations are close to the A1B results of BACC II, in spite of the stronger average global warming in the underlying RCP8.5 GCM ensemble compared to that in the A1B GCM ensemble. According to the two suites of GCMs, the difference in global mean by the end of the century is $0.7 \mathrm{~K}$, i.e. about $25 \%$. For summer, the differences are larger, and it cannot be generally concluded whether or not the regional sensitivity to global climate change is different from what it was in BACC II, or whether this is just caused by the concrete selections of models included in the two model suites.

The expected anthropogenic climate change for the Baltic Sea area is corroborated by the present results: temperature will increase, in step with global warming and with a northsouth gradient. In the northern part of the area in winter, the warming approaches twice the average global warming.

Precipitation increases over the entire area in winter, somewhat less in summer in the northern part of the domain, and it does not change significantly in summer in the southern part. Extreme precipitation, here the 10-year return value, increases systematically, particularly in summer, in the entire domain, with some simulations showing more than $50 \%$ increase. 
The large ensemble of simulations does not indicate a significant change in wind speed. However, individual model simulations show distinct differences. Consequently, there is a large uncertainty related to future wind speed change in the area.

Solar irradiation at the surface is not projected to change in summer, but the RCM simulations show some decrease in winter connected to more extensive cloud cover and potentially also less snow in the future. There is, however, a large uncertainty related to this, since many GCMs show the opposite sign of the trend.

Snow cover, measured as the average amount of snow on the ground in winter (DJF), is reduced drastically, particularly in the south of the Baltic Sea catchment area, where the relative decrease is close to $80 \%$.

With respect to coupled vs. uncoupled models, we find a stronger warming in the coupled model during winter which is most pronounced in areas that today are seasonally affected by sea ice. During summer, the coupled model shows weaker warming compared to the uncoupled model. The comparison between coupled and uncoupled versions of a small subset of projections with the RCA4 and RCA4-NEMO models generally confirms results by Gröger et al. (2021b), who found coupling effects for changes in most climate indices, most clearly over the interactively coupled open sea area. Notable differences outside the coupled region occur over regions of topographically elevated terrain likely as an artefact of different model resolution.

Code availability. All data manipulations in this study are straightforward and described in the paper.

Data availability. All data used in this publication are publicly available through the Earth System Grid Federation (ESGF) network, e.g. http://esgf-data.dkrz.de (DKRZ, 2022).

Supplement. The supplement related to this article is available online at: https://doi.org/10.5194/esd-13-133-2022-supplement.

Author contributions. OBC, as the main author, has coordinated the writing, contributed to all parts of the paper, constructed figures and supplementary material. EK has contributed to all parts of the paper, mainly regarding introduction and the atmospheric simulations. MM, MG and CD have contributed to all parts of the paper, with their main focus on the comparison of atmospheric models with ocean-atmosphere coupled regional models.

Competing interests. The contact author has declared that neither they nor their co-authors have any competing interests.
Special issue statement. This article is part of the special issue "The Baltic Earth Assessment Reports (BEAR)". It is not associated with a conference.

Disclaimer. Publisher's note: Copernicus Publications remains neutral with regard to jurisdictional claims in published maps and institutional affiliations.

Acknowledgements. The research presented in this study is part of the Baltic Earth Assessment Reports project of the Baltic Earth programme (Earth System Science of the Baltic Sea Region, https: //baltic.earth, last access: 14 January 2022). The authors would like to thank the EURO-CORDEX network and WCRP CORDEX for ensuring availability of CORDEX data.

It is with great sadness that we received the news that our coauthor, Christian Dieterich, passed away during the review of this paper.

Financial support. This study has been partly funded by the Copernicus Climate Change Service. ECMWF implements this service on behalf of the European Commission. Part of the funding is by the Danish state through the National Centre for Climate Research (NCKF).

Review statement. This paper was edited by Marcus Reckermann and reviewed by Jouni Räisänen and two anonymous referees.

\section{References}

Akhtar, N., Krug, A., Brauch, J., Arsouze, T., Dieterich, C., and Ahrens, B.: European Marginal Seas in a regional atmosphere-ocean coupled model and their impact on $\mathrm{Vb}$ cyclones and associated precipitation, Clim. Dynam., 53, 59675984, https://doi.org/10.1007/s00382-019-04906-x, 2019.

BACC Author Team: Assessment of Climate Change for the Baltic Sea Basin, Regional Climate Studies, Springer Verlag, Berlin, Heidelberg, ISBN 978-3-540-72785-9, 2008.

BACC II Author Team: Second Assessment of Climate Change for the Baltic Sea Basin, Regional Climate Studies, Springer Verlag, Berlin, Heidelberg, ISBN 978-3-319-16005-4, 2015.

Ban, N., Schmidli, J., and Schär, C.: Heavy precipitation in a changing climate: Does short-term summer precipitation increase faster?, Geophys. Res. Lett., 42, 1165-1172, https://doi.org/10.1002/2014GL062588, 2015.

Bartók, B., Wild, M., Folini, D., Lüthi, D., Kotlarski, S., Schär, C., Vautard, R., Jerez, S., and Imecs, Z.: Projected changes in surface solar radiation in CMIP5 global climate models and in EURO-CORDEX regional climate models for Europe, Clim. Dynam., 49, 2665-2683, https://doi.org/10.1007/s00382-016-34712, 2017

Benestad, R. E.: A new global set of downscaled temperature scenarios, J. Climate, 24, 2080-2098, https://doi.org/10.1175/2010JCLI3687.1, 2011 
Boé, J., Somot, S., Corre, L., and Nabat, P.: Large discrepancies in summer climate change over Europe as projected by global and regional climate models: causes and consequences, Clim. Dynam., 54, 2981-3002, https://doi.org/10.1007/s00382020-05153-1, 2020.

Buser, C. M., Künsch, H. R., and Schär, C.: Bayesian multi-model projections of climate: generalization and application to ENSEMBLES results, Clim. Res., 4, 227-241, 2010.

Christensen, J. H. and Christensen O. B.: Severe summertime flooding in Europe, Nature 421, 805-806, 2003.

Christensen, J. H. and Christensen, O. B.: A summary of the PRUDENCE model projections of changes in European climate by the end of the century, Climatic Change, 81, 7-30, 2007.

Christensen, O. B. and Kjellström, E.: Projections for Temperature, Precipitation, Wind, and Snow in the Baltic Sea Region until 2100, Oxford Research Encyclopedia of Climate Science, Oxford University Press, https://doi.org/10.1093/acrefore/9780190228620.013.695, 2018.

Christensen, J. H., Hewitson, B., Busuioc, A., Chen, A., Gao, X., Held, I., Jones, R., Kolli, R. K., Kwon, W. T., Laprise, R., Magaña, Rueda, V., Mearns, L., Menéndez, C. G., Räisänen, J., Rinke, A., Sarr, A., and Whetton, P.: Regional Climate Projections, in: Climate Change 2007: The Physical Science Basis. Contribution of Working Group I to the Fourth Assessment Report of the Intergovernmental Panel on Climate Change, edited by: Solomon, S., Qin, D., Manning, M., Chen, Z., Marquis, M., Averyt, K. B., Tignor, M., and Miller, H. L., Cambridge University Press, Cambridge, UK, 2007.

Christensen J. H., Kjellström E., Giorgi, F., Lenderink, G., and Rummukainen, M.: Weight assignment in regional climate models, Clim. Res., 44, 179-194, 2010.

Christensen O. B., Kjellström E., and Zorita E.: Projected Change-Atmosphere, in: Second Assessment of Climate Change for the Baltic Sea Basin, Regional Climate Studies, edited by: The BACC II Author Team, 217-234, Springer, https://doi.org/10.1007/978-3-319-16006-1_11, 2015a.

Christensen, O. B., Yang, S., Boberg, F., Maule, C. F., Thejll, P., Olesen, M., Drews, M., Sørup, H. J. D., and Christensen, J. H.: Scalability of regional climate change in Europe for high-end scenarios, Clim. Res., 64, 25-38, https://doi.org/10.3354/CR01286, 2015b.

Christensen, J. H., Larsen, M. A. D., Christensen, O. B., Drews, M., and Stendel, M.: Robustness of European climate projections from dynamical downscaling, Clim. Dynam., 53, 48574869, https://doi.org/10.1007/s00382-019-04831-z, 2019.

Coppola, E., Nogherotto, R., Ciarlo, J. M., Giorgi, F., Somot, S., Nabat, P., Corre, L., Christensen, O, B., Boberg, F., van Meijgaard, E., Aalbers, E., Lenderink, G., Schwingshackl, C., Sandstad, M., Sillmann, J., Bülow, K., Teichmann, C., Iles, C., Kadygrov, N., Vautard, R., Levavasseur, G., Sørland, S. L., Demory, M.-E., Kjellström, E., and Nikulin, G.: Assessment of the European climate projections as simulated by the large EURO-CORDEX regional climate model ensemble, J. Geophys. Res.-Atmos., 126, e2019JD032356, https://doi.org/10.1029/2019JD032356, 2021.

Déqué, M., Somot, S., Sanchez-Gomez, E., Goodess, C. M., Jacob, D., Lenderink, G., and Christensen O. B.: The spread amongst ENSEMBLES regional scenarios: regional climate models, driv- ing general circulation models and interannual variability, Clim. Dynam., 38, 951-964, 2012.

Dieterich, C., Wang, S., Schimanke, S., Gröger, M., Klein, B, Hordoir, R., Samuelsson, P., Liu, Y., Axell, L., Höglund, A., and Meier, H. E. M.: Surface heat budget over the North Sea in climate change simulations, Atmosphere, 10, 272, https://doi.org/10.3390/atmos10050272, 2019.

Donat, M. G., Leckebusch, G. C., Wild, S., and Ulbrich, U.: Future changes in European winter storm losses and extreme wind speeds inferred from GCM and RCM multi-model simulations, Nat. Hazards Earth Syst. Sci., 11, 1351-1370, https://doi.org/10.5194/nhess-11-1351-2011, 2011.

Dosio, A.: Projections of climate change indices of temperature and precipitation from an ensemble of biasadjusted high-resolution EURO-CORDEX regional climate models, J. Geophys. Res.-Atmos., 121, 5488-5511, https://doi.org/10.1002/2015JD024411, 2016.

Döscher, R., Willén, U., Jones, C., Rutgersson, A., Meier, H. E. M., Hansson, U., and Graham, L. P.: The development of the regional coupled ocean-atmosphere model RCAO, Boreal Environ. Res., 7, 183-192, 2002.

DKRZ: EURO-CORDEX data archive, available at, e.g., http:// esgf-data.dkrz.de, last access: 14 January 2022.

Dutheil, C., Meier, H. E. M, Gröger, M., and Börgel, F.: Understanding past and future sea surface temperature trends in the Baltic Sea, Clim. Dynam., https://doi.org/10.1007/s00382-02106084-1, 2021.

Eyring, V., Bony, S., Meehl, G. A., Senior, C. A., Stevens, B., Stouffer, R. J., and Taylor, K. E.: Overview of the Coupled Model Intercomparison Project Phase 6 (CMIP6) experimental design and organization, Geosci. Model Dev., 9, 1937-1958, https://doi.org/10.5194/gmd-9-1937-2016, 2016.

Feser, F., Weisse, R., and von Storch, H.: Multi-decadal atmospheric modeling for Europe yields multipurpose data, EOS Trans., 82, 305-310, 2001.

Gao, Y., Chen, F., and Jiang Y.: Evaluation of a convectionpermitting modeling of precipitation over the Tibetan Plateau and its infuences on the simulation of snow-cover fraction, J. Hydrometeorol., 21, 1531-1548, https://doi.org/10.1175/jhm-d19-0277.1, 2020.

Giorgi, F. and Gao X.-J.: Regional earth system modeling: Review and future directions, Atmospheric and Oceanic Science Letters, 11, 189-197, 2018.

Giorgi, F., Jones, C., and Asrar G. R.: Addressing climate information needs at the regional level: the CORDEX framework, WMO Bull., 58, 175-183, 2006.

Graham, L. P., Chen, D., Christensen, O. B., Kjellström, E., Krysanova, V., Meier H. E. M., Radziejewski, M., Rockel, B., Ruosteenoja, K., and Räisänen, J.: Projections of future climate change, in: Assessment of Climate Change for the Baltic Sea Basin, The BACC Author Team, XXI, 473 pp., Springer, ISBN 978-3-540-72785-9, 2008.

Gröger, M., Dieterich, C., Meier, H. E. M., and Schimanke S.: Thermal air-sea coupling in hindcast simulations for the North Sea and Baltic Sea on the NW European shelf, Tellus A, 67, 26911, https://doi.org/10.3402/tellusa.v67.26911, 2015.

Gröger, M., Arneborg, L., Dieterich, C., Höglund, A., and Meier, H. E. M.: Summer hydrographic changes in the Baltic Sea, Kattegat and Skagerrak projected in an ensemble of cli- 
mate scenarios downscaled with a coupled regional oceansea ice-atmosphere model, Clim. Dynam., 53, 5945-5966, https://doi.org/10.1007/s00382-019-04908-9, 2019.

Gröger, M., Dieterich, C., and Meier, H. E. M.: Is interactive air sea coupling relevant for simulating the future climate of Europe?, Clim. Dynam., 56, 491-514, https://doi.org/10.1007/s00382020-05489-8, 2021a.

Gröger, M., Dieterich, C., Haapala, J., Ho-Hagemann, H. T. M., Hagemann, S., Jakacki, J., May, W., Meier, H. E. M., Miller, P. A., Rutgersson, A., and Wu, L.: Coupled regional Earth system modeling in the Baltic Sea region, Earth Syst. Dynam., 12, 939973, https://doi.org/10.5194/esd-12-939-2021, 2021 b.

Gustafsson, N., Nyberg, L., and Omstedt, A.: Coupling of a highresolution atmospheric model and an ocean model for the Baltic Sea, Mon. Weather Rev., 126, 2822-2846, 1998.

Hagemann, S., Machenhauer, B., Jones, R., Christensen, O. B., Déqué, M., and Vidale P. L.: Evaluation of water and energy budgets in regional climate models applied over Europe, Clim. Dynam, 23, 547-567, 2004.

Hanel, M. and Buishand, A.: Analysis of precipitation extremes in an ensemble of transient regional climate model simulations for the Rhine basin, Clim. Dynam, 36, 1135-1153, 2011.

Held, I. and Soden, B: Robust response of the hydrological cycle to global warming, J. Climate, 19, 5686-5699, 2006.

Ho-Hagemann, H. T. M., Gröger, M., Rockel, B., Zahn, M., Geyer, B., and Meier, H. E. M.: Effects of air-sea coupling over the North Sea and the Baltic Sea on simulated summer precipitation over Central Europe, Clim. Dynam., 49, 3851, https://doi.org/10.1007/s00382-017-3546-8, 2017.

IPCC Climate Change 2001: The Scientific Basis, Contribution from Working Group I to the Third Assessment Report of the Intergovernmental Panel on Climate Change, edited by: Houghton, J. T., Ding, Y., Griggs, D. J., Noguer, M., van der Linden, P. J., Dai, X., Maskell, K., and Johnson, C. A., Cambridge University Press, Cambridge, UK, 2001.

IPCC Climate Change 2007: The Physical Science Basis, edited by: Solomon, S., Qin, D., Manning, M., Marquis, M., Averyt, K., Tignor, M. M. B., Miller, H. L., and Chen, Z., Cambridge University Press, Cambridge, UK, 2007.

IPCC Climate Change 2013: The Physical Science Basis, Contribution of Working Group I to the Fifth Assessment Report of the Intergovernmental Panel on Climate Change, edited by: Stocker, T. F., Qin, D., Plattner, G.-K., Tignor, M., Allen, S. K., Boschung, J., Nauels, A., Xia, Y., Bex, V., and Midgley, P. M., Cambridge University Press, Cambridge, United Kingdom and New York, NY, USA, 1535 pp., 2013.

IPCC Climate Change 2021: The Physical Science Basis, Contribution of Working Group I to the Sixth Assessment Report of the Intergovernmental Panel on Climate Change, edited by: Masson-Delmotte, V., Zhai, P., Pirani, A., Connors, S. L., Péan, C., Berger, S., Caud, N., Chen, Y., Goldfarb, L., Gomis, M. I., Huang, M., Leitzell, K., Lonnoy, E., Matthews, J. B. R., Maycock, T. K., Waterfield, T., Yelekçi, O., Yu, R., and Zhou, B., Cambridge University Press, ISBN 978-92-9169-158-6, 2021.

Jacob, D., Petersen, J., Eggert, B., Alias, A., Christensen, O. B., Bouwer, L. M., Braun, A., Colette, A., Déqué, M., Georgievski, G., Georgopoulou, E., Gobiet, A., Menut, L., Nikulin, G., Haensler, A., Hempelmann, N., Jones, C., Keuler, K., Kovats, S., Kröner, N., Kotlarski, S., Kriegsmann, A., Martin,
E., van Meijgaard, E., Moseley, C., Pfeifer, S., Preuschmann, S., Radermacher, C., Radtke, K., Rechid, D., Rounsevell, M., Samuelsson, P., Somot, S., Soussana, J.-F., Teichmann, C., Valentini, R., Vautard, R., Weber, B., and Yiou, P.: EUROCORDEX: new high-resolution climate change projections for European impact research, Reg. Environ. Change, 14, 563-578, https://doi.org/10.1007/s10113-013-0499-2, 2014.

Kelemen, F. D., Primo, C., Feldmann, H., and Ahrens, B.: Added Value of Atmosphere-Ocean Coupling in a CenturyLong Regional Climate Simulation, Atmosphere, 10, 537, https://doi.org/10.3390/atmos10090537, 2019.

Kendon, E., Roberts, N. M., Fowler, H. J., Roberts, M. J., Chan, S. C., and Senior, C. A.: Heavier summer downpours with climate change revealed by weather forecast resolution model, Nat. Clim. Change, 4, 570-576, https://doi.org/10.1038/nclimate2258, 2014.

Keuler, K., Radtke, K., Kotlarski, S., and Lüthi, D.: Regional climate change over Europe in COSMO-CLM: Influence of emission scenario and driving global model, Met. Z., 25, 121-136, https://doi.org/10.3929/ethz-b-000117030, 2016.

Kjellström, E.: Recent and future signatures of climate change in Europe, Ambio, 33, 193-198, 2004.

Kjellström, E. and Lind, P.: Changes in the water budget in the Baltic Sea drainage basin in future warmer climates as simulated by the regional climate model RCA3, Boreal Environ. Res., 14, 114-124, 2009.

Kjellström, E. and Christensen, O. B.: Regional Climate Modelling for the Baltic Sea Region, in: Climate of the Baltic Sea region, edited by: von Storch, H., Oxford Research Encyclopedia of Climate Science, Oxford University Press, USA, https://doi.org/10.1093/acrefore/9780190228620.013.700, 2020.

Kjellström, E. and Ruosteenoja, K.: Present-day and future precipitation in the Baltic Sea region as simulated in a suite of regional climate models, Climatic Change, 81, 281-291, https://doi.org/10.1007/s10584-006-9219-y, 2007.

Kjellström, E., Bärring, L., Jacob, D., Jones, R., Lenderink, G., and Schär, C.: Modelling daily temperature extremes: Recent climate and future changes over Europe, Climatic Change, 81, 249-265, 2007.

Kjellström, E., Nikulin, G., Hansson, U., Strandberg, G., and Ullerstig, A.: 21st century changes in the European climate: uncertainties derived from an ensemble of regional climate model simulations, Tellus A, 63, 24-40, 2011.

Kjellström, E., Thejll, P., Rummukainen, M., Christensen, J. H., Boberg, F., Christensen, O. B., and Fox Maule, C.: Emerging regional climate change signals for Europe under varying largescale circulation conditions, Clim Res., 56, 103-119, 2013.

Kjellström, E., Bärring, L., Nikulin, G., Nilsson, C., Persson, G., and Strandberg, G.: Production and use of regional climate model projections - a Swedish perspective on building climate services, Climate Services, 2-3, 15-29, https://doi.org/10.1016/j.cliser.2016.06.004, 2016.

Kjellström, E., Nikulin, G., Strandberg, G., Christensen, O. B., Jacob, D., Keuler, K., Lenderink, G., van Meijgaard, E., Schär, C., Somot, S., Sørland, S. L., Teichmann, C., and Vautard, R.: European climate change at global mean temperature increases of 1.5 and $2{ }^{\circ} \mathrm{C}$ above pre-industrial conditions as simulated by the EURO-CORDEX regional climate models, Earth Syst. Dynam., 9, 459-478, https://doi.org/10.5194/esd-9-459-2018, 2018. 
Kotlarski, S., Keuler, K., Christensen, O. B., Colette, A., Déqué, M., Gobiet, A., Goergen, K., Jacob, D., Lüthi, D., van Meijgaard, E., Nikulin, G., Schär, C., Teichmann, C., Vautard, R., Warrach-Sagi, K., and Wulfmeyer, V.: Regional climate modeling on European scales: a joint standard evaluation of the EUROCORDEX RCM ensemble, Geosci. Model Dev., 7, 1297-1333, https://doi.org/10.5194/gmd-7-1297-2014, 2014.

Kyselý, J., Gaál, L., Beranová, R., and Plavcová, E.: Climate change scenarios of precipitation extremes in Central Europe from ENSEMBLES regional climate models, Theor. Appl. Climatol, 104, 529-542, 2011.

Larsen, A. N., Gregersen, I. B., Christensen, O. B., Linde, J. J., and Mikkelsen, P. S.: Potential future increase in extreme one-hour precipitation events over Europe due to climate change, Water Sci. Tech., 60, 2205-2216, 2009.

Lenderink, G. and van Meijgaard, E.: Linking increases in hourly precipitation extremes to atmospheric temperature and moisture changes, Environ. Res. Lett. 5, 025208, https://doi.org/10.1088/1748-9326/5/2/025208, 2010.

Lenderink, G., Belušić, D., Fowler, H., Kjellström, E., Lind, P., van Meijgaard, E., van Ulft, B., and de Vries, H.: Systematic increases in the thermodynamic response of hourly precipitation extremes in an idealized warming experiment with a convection-permitting climate model, Environ. Res. Lett., 14, 074012, https://doi.org/10.1088/1748-9326/ab214a, 2019.

Lind, P. and Kjellström, E.: Temperature and precipitation changes in Sweden; a wide range of model-based projections for the 21st century, SMHI Reports Meteorology and Climatology, 113, ISSN 0347-2116, 2008.

Lind, P., Lindstedt, D., Kjellström, E., and Jones, C.: Spatial and Temporal Characteristics of Summer Precipitation over Central Europe in a Suite of High- Resolution Climate Models, J. Climate, 29, 3501-3518, https://doi.org/10.1175/JCLI-D-150463.1, 2016

Lind, P., Belušić, D., Christensen, O. B., Dobler, A., Kjellström, E., Landgren, O., Lindstedt, D., Matte, D., Pedersen, R. A., Toivonen, E., and Wang, F. : Benefits and added value of convectionpermitting climate modeling over Fenno-Scandinavia, Clim. Dynam., 55, 1893-1912, https://doi.org/10.1007/s00382-02005359-3, 2020.

Lindvall, J. and Svensson, G.: The diurnal temperature range in the CMIP5 models, Clim. Dynam, 44, 405-421, https://doi.org/10.1007/s00382-014-2144-2, 2015.

Meier, H. E. M., Höglund, A., Döscher, R., Andersson, H., Löptien, U., and Kjellström, E.: Quality assessment of atmospheric surface fields over the Baltic Sea from an ensemble of regional climate model simulations with respect to ocean dynamics, Oceanologia, 53, 193-227, 2011.

Nakićenović, N., Alcamo, J., Davis, G., de Vries, B., Fenhann, J., Gaffin, S., Gregory, K., Grübler, A., Jung, T. Y., Kram, T., la Rovere, E. L., Michaelis, L., Mori, S., Morita, T., Pepper, W., Pitcher, H., Price, L., Riahi, K., Roehrl, A., Rogner, H.-H., Sankovski, A., Schlesinger, M., Shukla, P., Smith, S., Swart, R., van Rooijen, S., Victor, N., and Zhou, D.: Emission scenarios. A Special Report of Working Group III of the Intergovernmental Panel on Climate Change, Cambridge University Press, 599 pp., ISBN 92-9169-113-5, 2000.

Nikulin, G., Kjellström, E., Hansson, U., Jones, C., Strandberg, G., and Ullerstig, A.: Evaluation and future projections of tempera- ture, precipitation and wind extremes over Europe in an ensemble of regional climate simulations, Tellus A, 63, 41-55, 2011.

Nilsen, I. B., Hanssen-Bauer, I., Tveito, O. E., and Wong, W. K.: Projected changes in days with zero crossings for Norway, Int. J. Climatol., 2021, 41, 2173-2188, https://doi.org/10.1002/joc.6913, 2021.

O’Neill, B. C., Kriegler, E., Ebi, K. L., Kemp-Benedict, E., Riahi, K., Rothman, D. S., van Ruijven, B. J., van Vuuren, D. P., Birkmann, J., Kok, K., Levy, M., and Solecki, W.: The roads ahead: Narratives for shared socioeconomic pathways describing world futures in the 21st century, Global Environ. Chang., 42, 169-180, https://doi.org/10.1016/j.gloenvcha.2015.01.004, 2017.

Prein, A. F., Gobiet, A., Truhetz, H., Keuler, K., Goergen, K., Teichmann, C., Fox Maule, C., van Meijgaard, E., Déqué, M., Nikulin, G., Vautard, R., Colette, A., Kjellström, E., and Jacob, D.: Precipitation in the EURO-CORDEX $0.11^{\circ}$ and $0.44^{\circ}$ simulations: high resolution, high benefits?, Clim. Dynam., 46, 383412, https://doi.org/10.1007/s00382-015-2589-y, 2015.

Primo, C., Kelemen, F. D., Feldmann, H., Akhtar, N., and Ahrens, B.: A regional atmosphere-ocean climate system model (CCLMv5.0clm7-NEMOv3.3-NEMOv3.6) over Europe including three marginal seas: on its stability and performance, Geosci. Model Dev., 12, 5077-5095, https://doi.org/10.5194/gmd-125077-2019, 2019.

Räisänen, J.: Probabilistic projections of temperature and precipitation change for the period 2021-2050, in: Proc. Future Climate and Renewable Energy: Impacts, Risks and Adaptation, 31 May2 June 2010, Oslo, 78-79, 2010.

Räisänen, J. and Eklund, J.: 21st century changes in snow climate in northern Europe: a high-resolution view from ENSEMBLES regional climate models, Clim. Dynam., 38, 2575-2591, 2011.

Räisänen, J.: Snow conditions in northern Europe: the dynamics of interannual variability versus projected long-term change, The Cryosphere, 15, 1677-1696, https://doi.org/10.5194/tc-15-16772021, 2021.

Ruosteenoja, K. and Räisänen, P.: Seasonal changes in solar radiation and relative humidity in Europe in response to global warming, J. Climate, 26, 2467-2481, https://doi.org/10.1175/JCLI-D12-00007.1, 2013.

Samuelsson, P., Jones, C., Willén, U., Ullerstig, A., Gollvik, S., Hansson, U., Kjellström, E., Nikulin, G., and Wyser, K.: The Rossby Centre Regional Climate Model RCA3: Model description and performance, Tellus A, 63, 4-23, 2011.

Schuler, D. V., Beldring, S., Førland, E. J., Roald, L. A., and EngenSkaugen, T.: Snow cover and snow water equivalent in Norway: current conditions (1961-1990) and scenarios for the future (2071-2100), Met No Report, no. 01/2006 Climate, Oslo, Norway, ISSN 1503-8025, 2006.

Sein, D. V, Gröger, M., Cabos, W., Alvarez, F., Hagemann, S., de la Vara, A., Pinto, J. G., Izquierdo, A., Koldunov, N. V., Dvornikov, A. Y., Limareva, N., Martinez, B., and Jacob, D.: Regionally coupled atmosphere - ocean - marine biogeochemistry model ROM: 2. Studying the climate change signal in the North Atlantic and Europe, J. Adv. Model. Earth Syst., 12, e2019MS001646, https://doi.org/10.1029/2019MS001646, 2020.

Seneviratne, S. I., Nicholls, N., Easterling, D., Goodess, C. M., Kanae, S., Kossin, J., Luo, Y., Marengo, J., McInnes, K., Rahimi, M., Reichstein, M., Sorteberg, A., Vera, C., and Zhang, X.: Changes in climate extremes and their impacts on the natural 
physical environment, in: Managing the Risks of Extreme Events and Disasters to Advance Climate Change Adaptation, edited by: Field, C. B., Barros, V., Stocker, T. F., Qin, D., Dokken, D. J., Ebi, K. L., Mastrandrea, M. D., Mach, K. J., Plattner, G.-K., Allen, S. K., Tignor, M., and Midgley, P. M.: A Special Report of Working Groups I and II of the Intergovernmental Panel on Climate Change (IPCC), Cambridge University Press, Cambridge, UK, and New York, NY, USA, 109-230, 2012.

Strandberg, G., Bärring, L., Hansson, U., Jansson, C., Jones, C., Kjellström, E., Kolax, M., Kupiainen, M., Nikulin, G., Samuelsson, P., Ullerstig, A., and Wang, S.: CORDEX scenarios for Europe from the Rossby Centre regional climate model RCA4, Reports Meteorology and Climatology, 116, SMHI, SE-60176 Norrköping, Sverige, ISSN 0347-2116; 116, 2014.

Sutton, R. T., Dong, B., and Gregory, J. M.: Land/sea warming ratio in response to climate change: IPCC AR4 model results and comparison with observations, Geophys. Res. Lett., 34, L02701, https://doi.org/10.1029/2006GL028164, 2007.

Taylor, K. E., Stouffer, R. J., and Meehl, G. A.: An overview of CMIP5 and the experiment design, B. Am. Meteorol. Soc., 93, 485-498, https://doi.org/10.1175/BAMS-D-11-00094.1, 2012.

Tobin, I., Jerez, S., Vautard, R., Thais, F., Déqué, M., Kotlarski, S., Fox Maule, C., van Meijgaard, E., Nikulin, G., Noël, T., Prein, A., and Teichmann, C..: Climate change impacts on the power generation potential of a European midcentury wind farms scenario, Environ. Res. Lett., 11, 034013, https://doi.org/10.1088/1748-9326/11/3/034013, 2016.

van der Linden, P. and Mitchell, J. F. B.: ENSEMBLES: climate change and its impacts: summary of research and results from the ENSEMBLES project, Met Office, Hadley Centre, Exeter, UK, available at: https://ensembles-eu.metoffice.gov. uk/docs/Ensembles_final_report_Nov09.pdf (last access: 14 January 2022), 2009. van Vuuren, D. P., Edmonds, J. A., Kainuma, M., Riahi, K., and Weyant, J.: A special issue on the RCPs, Climatic Change 109, $1-4,2011$.

Vautard, R., Gobiet, A., Sobolowski, S., Kjellström, E., Stegehuis, A., Watkiss, P., Mendlik, T., Landgren, O., Nikulin, G., Teichmann, C., and Jacob, D.: The European climate under a $2{ }^{\circ} \mathrm{C}$ global warming, Environ. Res. Lett., 9, 034006, https://doi.org/10.1088/1748-9326/9/3/034006, 2014.

Vautard, R., Kadygrov, N., Iles, C., Boberg, F., Buonomo, E., Bülow, K., Coppola, E., Corre, L., van Meijgaard, E., Nogherotto, R., Sandstad, M., Schwingshackl, C., Somot, S., Aalbers, E., Christensen, O. B., Ciarlo, J. M., Demory, M.-E., Giorgi, F., Jacob, D., Jones, R. G., Keuler, K., Kjellström, E., Lenderink, G., Levavasseur, G., Nikulin, G., Sillmann, J., Solidoro, C., Sørland, S. L., Steger, C., Teichmann, C., Warrach-Sagi, K., and Wulfmeyer, V.: Evaluation of the large EURO-CORDEX regional climate model ensemble, J. Geophys. Res., 126, e2019JD032344, https://doi.org/10.1029/2019JD032344, 2021.

Wang, S., Dieterich, C., Döscher, R., Höglund, A., Hordoir, R., Meier, H., Samuelsson, P., and Schimanke, S.: Development and evaluation of a new regional coupled atmosphere ocean model in the North Sea and Baltic Sea, Tellus A, 67, 24284, https://doi.org/10.3402/tellusa.v67.24284, 2015.

Wibig, J., Mauran, D., Benestad, R., Kjellström, E., Lorenz, P., and Christensen, O. B.: Projected Change - Models and Methodology, edited by: The BACC II Author Team, Second Assessment of Climate Change for the Baltic Sea Basin, Regional Climate Studies, 189-216, Springer, available at: https://link. springer.com/chapter/10.1007/978-3-319-16006-1_10 (last access: 14 January 2022), 2015. 